\title{
The implications of selenium deficiency for wild herbivore conservation: a review
}

\author{
W. T. Flueck • J. M. Smith-Flueck • J. Mionczynski • B. J. Mincher
}

Received: 21 October 2011 /Revised: 9 June 2012 / Accepted: 20 June 2012 /Published online: 13 July 2012

(C) Springer-Verlag 2012

\begin{abstract}
Selenium (Se) is required at a fundamental physiological level in all animals. Adequate levels of Se are necessary for proper bone metabolism, iodine metabolism, immune function, reproductive success, and recruitment. Selenium is a component of enzymes which scavenge oxidative free radicals that would otherwise degrade cell membranes. Severe deficiency results in obvious symptoms such as white muscle disease in ungulates. However, more frequently, deficiency may be chronic and subclinical. Individuals then display no obvious signs of malady, yet performance suffers until their populations decline without
\end{abstract}

Communicated by H. Kierdorf

W. T. Flueck $(\bowtie)$

National Council of Scientific and Technological Research (CONICET),

Buenos Aires, Argentina

e-mail: wtf@deerlab.org

\section{W. T. Flueck}

Fundación Bariloche,

8400 Bariloche, Argentina

W. T. Flueck

Swiss Tropical and Public Health Institute, University Basel,

Basel, Switzerland

W. T. Flueck · J. M. Smith-Flueck

Institute of Natural Resources Analysis-Patagonia,

Universidad Atlantida Argentina,

C.C. 592 ,

8400 Bariloche, Argentina

J. Mionczynski

Wildlife Consultant,

70 Three Forks Road,

Atlantic City, WY 82520, USA

\section{B. J. Mincher}

Aqueous Separations and Radiochemistry Department, Idaho National Laboratory,

PO Box 1625, Idaho Falls, ID 83415, USA apparent cause or through proximate factors which obscure underlying primary factors. Although well known in domestic stock, the link between population performance and Se deficiency in wild populations has been difficult to firmly establish. Confounding factors include the role of vitamin E, which also acts as an antioxidant to mitigate the need for Se under some circumstances; changing Se requirements at changing times in animal life history; changing Se requirements in relation to pollution levels and other factors causing oxidative stress; and the non-uniform distribution of Se in its various chemical forms in the environment. The latter point is especially important to wild populations that have been reduced to remnant portions of their previous range. Here, we have reviewed the literature of Se in wildlife as well as provided an introduction to Se in physiology and Se behavior in the environment for the wildlife researcher and manager. We conclude that unrecognized Se deficiency may often impede optimal population performance, and we provide recommendations for habitat analysis with regard to Se which can be used in future research. Finally, evidence that the amount of available $\mathrm{Se}$ in the environment is decreasing from anthropogenic causes is shown.

Keywords Biogeochemical cycle $\cdot$ Environmental chemistry $\cdot$ Iodine $\cdot$ Micronutrient deficiency $\cdot$ Nutritional ecology $\cdot$ Nutritional muscular dystrophy $\cdot$ Selenium $\cdot$ White muscle disease $\cdot$ Wild ungulates $\cdot$ Wildlife conservation

\section{Introduction}

Selenium (Se) has been identified as an essential micronutrient in all animals. It is required at the most fundamental physiological level as a component of the 21st amino acid, selenocysteine. Adequate levels of Se are vital to proper reproductive performance, bone metabolism, immune function, and iodine 
metabolism. Yet, Se is a relatively rare element and is often present at low concentrations in soil and vegetation. It has the lowest concentration in igneous bedrock of all the nutrient elements and is unevenly distributed in the landscape and frequently at deficient levels for terrestrial herbivores. Selenium deficiencies are widespread in domestic stock and are unavoidable in some wildlife populations. This may be especially true for populations confined to high-elevation ranges or on areas with granitic bedrock or volcanic soils with low Se content or that have lost access to Se-enriched parts of their ranges such as mineral licks or low-elevation winter range. The condition may be exacerbated by increased levels of oxidative stress. Herbivores acquire their Se primarily from plants. As plants do not require Se, their levels depend on geological and climatic factors, that is, on the environmental chemistry of $\mathrm{Se}$ and its chemical speciation in the environment.

Because our understanding of $\mathrm{Se}$ as a micronutrient is relatively new, many wildlife managers are unaware of the element's importance in physiology and population dynamics. Severe deficiency in ungulates results in obvious symptoms such as white muscle disease (WMD). More frequently, deficiency is chronic and subclinical. Individuals then display no obvious signs of malady, yet performance suffers until their populations decline without apparent cause. While mysterious population declines are not always due to Se deficiency, the wildlife manager should be aware of the possibility. Furthermore, animal requirements for Se are not static and depend on life stage, levels of pollution, and other factors causing oxidative stress. Therefore, this review not only presents a summary of the wildlife literature regarding Se nutrition but also looks at the role of $\mathrm{Se}$ in mammalian physiology and the environmental chemistry of this important element which affects its availability to wildlife.

\section{Discussion}

Selenium in physiology

\section{Biochemical roles}

Although Se was long known to have toxic affects at high doses, it was not until 1957 that it was found to have an essential physiological role in mammals, when it was shown to mitigate liver necrosis in rats (Schwarz and Foltz 1957). Shortly thereafter, it was also shown to prevent muscular degeneration in lambs (Schubert et al. 1961). It is now known that Se is crucial to all aerobically respiring organisms and is so fundamental that the genetic code was expanded following the recognition of the 21 st naturally occurring amino acid, selenocysteine. This Se-containing amino acid is essential in all mammals (Tate et al. 1999;
Hatfield and Gladyshev 2002). Some 35 selenoproteins have now been identified in animals and humans, all containing selenocysteine in their active sites (Arthur 2000; Kryukov et al. 2003; Raymond and Ralston 2004). A review of the selenoenzymes and other selenoproteins was provided by Stadtman (1990), and the number of functional selenoproteins as well as the range of biological roles for individual selenoproteins continue to expand (Reeves and Hoffmann 2009).

The most important known functions of selenoproteins are in antioxidant defense, including the elimination of active oxygen species such as hydrogen peroxide, hydroperoxides, and oxygen-containing free radicals - the toxic products of aerobic respiration (Shchedrina et al. 2010). These reactive oxygen species react with unsaturated lipid compounds, causing the degradation of cell membranes. Four glutathione peroxidases (GPX) as well as thioredoxin reductase and other selenoproteins act as oxidant scavengers in various tissues. Sakuma et al. (2008), for example, demonstrated that rats denied Se exhibited low liver Se concentrations, low GPX activity, and higher bile hydrogen peroxide and oxidative stress levels. Similarly, 65 domestic cattle with initially $0.058 \mathrm{mg} / \mathrm{kg}$ wet weight (ww) liver Se and GPX activity of $35 \mathrm{IU} / \mathrm{g}$ hemoglobin, when treated with Se boluses, exhibited an increase in liver Se to $0.070 \mathrm{mg} / \mathrm{kg}$ (ww) and GPX activity of $263 \mathrm{IU} / \mathrm{g}$ (Hidiroglou et al. 1987). Similarly, 20 domestic lambs with WMD were found to have low mean liver concentrations of $0.088 \mathrm{mg} / \mathrm{kg}$ (ww) Se and GPX activity of $22.3 \mathrm{IU} / \mathrm{g}$ vs. $0.515 \mathrm{mg} / \mathrm{kg}$ (ww) Se and $34.0 \mathrm{IU} / \mathrm{g}$ for healthy lambs $(P<0.001)$ (Beytut et al. 2002). Selenium deficiency also has effects on the blood and blood formation. Oxidative stress causes the denaturation of the globin subunits of hemoglobin, and Se deficiency makes erythrocytes osmotically fragile, increases erythropoietin levels, and leads to inefficient erythropoiesis (Kaushal et al. 2011).

Selenoprotein synthesis is important to early mammalian development, as illustrated by the findings of Serdaru et al. (2004) who reported that even during periods of Se deficiency, domestic cattle dams continued to supply high-Se colostrum to their calves through depletion of their own reserves. Genomic studies have identified a protein homologous to selenoprotein $\mathrm{N}$ that is unique to vertebrates (Rederstorff et al. 2006), and mutations in the gene SEPN 1 cause a form of congenital muscular dystrophy. Sequencing of the gene from patients affected with this muscular dystrophy have identified several mutations, establishing for the first time a connection between a selenoprotein and a human genetic disorder (Rederstorff et al. 2006). Congenital muscular dystrophy causes muscle pain and rigidity of the limbs and spine. Also, at least six selenoproteins are residents of the endoplasmic reticulum, revealing an important role in its function which is only 
beginning to be understood. These selenoproteins are mainly involved in protein folding and the disposition of misfolded proteins (Shchedrina et al. 2010). Four of these selenoproteins are nearly exclusive to vertebrates (Reeves and Hoffmann 2009; Shchedrina et al. 2010).

Although this review highlights Se, the element also interacts with iodine by affecting its role in thyroid hormone metabolism; a brief summary of these affects is warranted here. Selenium deficiency causes secondary iodine deficiency in vertebrates (Zagrodzki et al. 1998; Arthur et al. 1999; Köhrle 2005; Duntas 2010). Iodine deficiency results in abortions, stillbirths, reduced fetal weight, weak neonates, increased neonatal mortality, prolonged gestation, and infertility (Kalkus 1920; Schlumberger 1955; Barry 1983; Wilson et al. 2002; Sivertsen 2004; Ebert et al. 2008). Juvenile growth - even under subclinical iodine deficiency - is impaired (Choudhury and Gorman 2003), neurological development is aberrant, plus various other less specific symptoms (Potter et al. 1982; Matomoros et al. 2003).

Selenium is necessary for the conversion of the inactive thyroid hormone thyroxine $\left(\mathrm{T}_{4}\right)$ into its more active counterpart, triiodothyronine $\left(\mathrm{T}_{3}\right)$, via the action of one of three Se-containing deiodinase enzymes (Wichtel et al. 1996; Köhrle 2000). The hormone $T_{3}$ is required for normal growth and development, and for energy production and oxygen consumption in cells. Selenium supplementation in deficient cattle results in higher $\mathrm{T}_{3}$ activity and higher immunoglobulin concentrations in colostrum (Voudouri et al. 2003; Pavlata et al. 2004), and Se-deficient lambs have been shown to have low levels of $\mathrm{T}_{3}$ and GPX, which are possibly responsible for a high incidence of stillbirths and neonatal deaths (Kozat 2007; Dalir-Naghadeh and Rezaei 2008). For example, Dalir-Naghadeh and Rezaei (2008) compared 35 domestic lambs suffering from the Se deficiency malady WMD with 30 healthy lambs and found that the mean erythrocyte GPX activity was higher in the healthy lambs (132 vs. $45 \mathrm{IU} / \mathrm{g}$ hemoglobin) and that the mean serum $\mathrm{T}_{4}$ concentration was lower in healthy lambs (58 vs. $77 \mathrm{nmol} / \mathrm{L}$ ). Meanwhile, serum $\mathrm{T}_{3}$ concentration was higher in the healthy group ( 1.9 vs. $1.4 \mathrm{nmol} / \mathrm{L}, P<0.001)$. Thus, $\mathrm{Se}$ deficiency can cause symptoms of hypothyroidism, including extreme fatigue or mental slowing, and may thus influence even basic metabolic and cold stress survival rates (Suttle 2010). The thyroid gland employs at least 11 selenoproteins, including selenoperoxidases, to protect it from hydrogen peroxide (Arthur et al. 1999; Beckett and Arthur 2005; Reeves and Hoffmann 2009).

Vitamin E, also acquired by herbivores from the plants they eat, plays an important antioxidant role protecting membrane lipids by inhibiting hydroperoxides and reducing GPX requirements (McDowell 1989). Both dietary vitamin $\mathrm{E}$ and Se protect against membrane lipid peroxidation, with vitamin E acting as a lipid-soluble, membrane-bound antioxidant and Se in GPX as a scavenger of oxidative free radicals and hydrogen peroxide in aqueous solution (Combs and Scott 1977). While the two would thus act cooperatively to protect all types of cells from reactive oxygen species, the vitamin can reduce the physiological requirement for Se and complicate the interpretation of the effects of Se deficiency. For example, Brady et al. (1978) found that when captive white-tailed deer (Odocoileus virginianus) were supplemented with vitamin $\mathrm{E}$, the incidence of WMD in their young was decreased even when the animals were maintained on a Se-marginal (although not necessarily deficient) diet of 40 ppb. However, Dierenfeld and Jessup (1990) reported that vitamin $\mathrm{E}$ deficiency alone was not sufficient to cause mortality in white-tailed deer. In that work, most mortality occurred when Se was also deficient. Since the production of reactive oxygen species is increased under stressful conditions, the need for $\mathrm{Se}$ and vitamin $\mathrm{E}$ is also increased under such conditions.

\section{Deficiency maladies}

The most overt malady associated with Se deficiency is WMD, also called nutritional muscular dystrophy. Well known from domestic livestock, it has also been reported in wild populations. It typically occurs in Se-deficient young at 3-6 weeks. Sometimes called "stiff lamb disease" or "weak fawn syndrome," it results in muscle stiffness and respiratory distress. Symptoms include slumped shoulders and a stiff-legged gait, poor growth, and high respiratory rates with nasal secretions and coughing and general unthriftiness. The skeletal and cardiac muscles may be affected, and myocardial necrosis may lead to sudden death (Suttle 2010). For wildlife, the decreased ability to move freely would be expected to lead to increased predation losses, as reported by Hnilicka et al. (2004). This applies particularly to neonates as females may suffer from small udder size, low milk production, and thus causing early weaning (Hnilicka et al. 2004).

Subclinical deficiency has less overt effects. Since it functions at a very basic biochemical level, Se deficiency may be expressed in myriad ways, and only pronounced deficiency is lethal (Rucker et al. 2008; Rederstorff et al. 2006). Under conditions of deficiency, the less essential selenoproteins are lost first, with those involved in survival to maturity and reproduction being conserved (McCann and Ames 2011).

In all animal species studied, prolonged Se deficiency impairs the reproductive performance of both males and females. It affects litter size, conception rate, embryonic mortality, birth weight, age of first breeding, neonatal mortality, and growth rate and also causes the retention of placentas (Allen and Ullrey 2004; Bogden et al. 2006; Kumar et al. 2009). Selenium deficient ewes in New 
Zealand and Australia, for example, were found to have a $20-50 \%$ infertility rate with high lamb losses (Suttle 2010). Ren et al. (2011) showed that successful completion of meiosis in the testes of offspring depends on both maternal and dietary Se supply. For Se-deficient males, sperm count and fertility are sharply reduced even though some sperm motility may persist, and damaged DNA in the sperm also affects the health of the offspring (Pfeifer et al. 2001; Allen and Ullrey 2004; Rederstorff et al. 2006). Maternal Se nutrition during gestation affects the efficiency of growth in offspring irrespective of postnatal management (Neville et al. 2010).

Furthermore, Se deficiency in postnatal and adult animals impairs bone metabolism, causing osteopenia and osteoarthritis (Moreno-Reyes et al. 1998, 2001; Köhrle et al. 2005; Ebert and Jakob 2007; Ren et al. 2007; Ebert et al. 2008), including Kashin-Beck disease in humans (Downey et al. 2009). Selenium deficiency in ruminants has similarly been shown to be an underlying factor for periodontitis, mandibular thickening, premature tooth shedding, and reduced bone density (Andrews et al. 1968; Porter et al. 1970; Van Reenan 1980). Examples of Se-related periodontal abnormalities in wildlife have been reported for wild sheep (Hnilicka et al. 2004) and, apparently, for huemul deer (Flueck and Smith-Flueck 2008).

Selenium is also fundamental for proper immune function and infectious disease resistance, and the pathogenicity of several disease organisms is likely based on the sequestration of Se from host cells (Taylor et al. 1997; Kasaikina et al. 2011). It significantly affects response to viral infections in its role as an antioxidant (Levander et al. 1995). The discovery of selenocysteine as the $21 \mathrm{st}$ amino acid led to predictions and later confirmation that a selenoprotein gene in HIV was a virally encoded homolog of GPX (Taylor et al. 1997). Similarly, the role of coxsackievirus in human Keshan disease has parallels to Se deficiency in coxsackievirus-infected mice and triggered a similar cardiomyopathy, called "viral myocarditis." Intriguingly, even a "benign" strain of coxsackievirus becomes virulent in Se-deficient mice, where it mutates into a more virulent strain that can produce myocarditis even when transferred to normal mice that are not Se-deficient (Levander et al. 1995; Taylor et al. 1997). Thus, these viral mutations are consistent rather than stochastic, and long-lived (Harthill 2011). Similarly, Se-deficient hosts were more susceptible to Listeria infections (Wang et al. 2009).

In addition to infectious diseases, Se deficiency also affects cancer prevention, aging processes, and, as discussed above, iodine metabolism (Arthur et al. 1999; Hatfield and Gladyshev 2002; Allen and Ullrey 2004). Primary deficiency can be due simply to living at high elevation and be associated with multidimensional stressors including hypoxia, cold and heat exposure, nutrition, and disease state, all of which raise oxidative stress (Iyengar and GopalAyengar 1988; Bakonyi and Radak 2004).

Selenium deficiency can elicit epigenetic effects; marginal deficiency can lead to up- or downregulation of certain enzymes, underscoring how sensitive organisms are to changes in Se homeostasis. For example, Mueller et al. (2010) found that target gene expression was upregulated in the intestine, possibly because it is in the first line of defense from the food side. In contrast, moderate Se deficiency resulted in the downregulation of genes involved in inflammation and heme biosynthesis, pointing to a disturbance in inflammatory response (Kipp et al. 2012). Selenium even influences the expression of multiple genes that code for non-selenoproteins. Selenium can prevent cysteine insertion into selenoproteins and thereby maximize its own enzymatic activity. For mice maintained on a Se-deficient diet, the ratio of selenocysteine/cysteine was $\sim 1: 1$, while on an adequate diet it was 9:1. Cysteine was not detected in mice selenoproteins on an enhanced diet (Turanov et al. 2011).

\section{Heavy metal scavenging}

The deposition of atmospheric mercury and cadmium has doubled between the beginning of the nineteenth century and 1990; from 1977 to 1990, the atmospheric concentration of mercury has increased by $1.5 \%$ per year in the Northern Hemisphere, with the anthropogenic flux being about 2.5fold larger than the natural one (Berger et al. 1989; Slemr and Langer 1992; Jackson 1997). Consequently, increased levels of heavy metals in wild herbivores have been documented (Backhaus and Backhaus 1983). The exposure of mammals to heavy metals increases the physiological need for Se because these metals may sequester Se (Sørmo et al. 2011). For example, in Se-depauperate Lake Mjøsa, Norway, Sørmo et al. (2011) found that the $\mathrm{Se} / \mathrm{Hg}$ ratio in brown trout (Salmo trutta) muscle tissue was a good predictor of the metallothionein concentration. Metallothionein is a cysteine-rich protein which scavenges mercury and cadmium; fish with low Se levels required more of it to scavenge mercury. Similarly, cadmium mobilization was much more efficient in Se-adequate than in Se-deficient rats (Kotyzová et al. 2010). Therefore, Se can be used to counteract the toxicity of heavy metals (Frost 1987; Whanger 1992) through complexation with selenoprotein P (Suttle 2010) or by reaction with Se itself to produce insoluble selenides (Sørmo et al. 2011). Numerous studies in many species have shown that Se supplementation counteracts the neurotoxicity, fetotoxicity, and developmental toxicity associated with mercury exposure (Raymond and Ralston 2004; Usuki et al. 2011). Furthermore, exposure to methylmercury induces Se deficiency by sequestering Se within hours and affecting epigenetically the expression of Se-dependent 
enzymes. The UGA codon for selenocysteine is then no longer recognized, resulting in incomplete protein synthesis (Usuki et al. 2011). The mercury-Se interaction has been implicated in low reproductive success for endangered leatherback turtles (Dermochelys coriacea; Perrault et al. 2011). In addition to heavy metals, chlorinated hydrocarbon exposure has also been implicated in raising Se requirements (Combs and Scott 1977).

In summary, subclinical Se deficiencies are generically expressed as reduced immune function, reduced systemic growth and reproductive potential, and behavioral changes due both to Se deficiency malady and, possibly, secondary impairment of iodine metabolism. These subtle affects are not easily recognized, but will affect population performance. The absence of clinical signs has long been considered inappropriate as evidence for adequate mineral nutrition (Hebert and Cowan 1971a). Although subclinical deficiencies are probably widespread, they are rarely recognized in wildlife (Robbins 1983; Flueck 1994; Sargison et al. 1998; Mincher et al. 2008) or in extensive animal production systems (Johnson et al. 1979; Jones et al. 1987). Unfortunately, subclinical deficiency is not easily detected and requires production trials for its verification (Sargison et al. 1998; Grace and Wilson 2002).

\section{Selenium in wildlife}

\section{General considerations}

Although overt symptoms of deficiency are seldom reported for wild populations, the selenium status of wildlife populations has been studied around the globe, often due to suspicions about its subclinical effects. Typically, liver or whole-blood concentrations are sampled, although the value of comparisons between studies may be limited. It must be recognized that the mineral status of an individual animal may depend on age, sex, species, season, reproductive status, and the level of oxidative stress. As previously mentioned, high levels of vitamin E may mitigate the need for elevated Se. Furthermore, differing sampling and analytical techniques may affect Se measurement results. For this discussion, all reported liver values have been converted to wet weight for ease of comparison, assuming that wet weight concentrations are a factor of 4 lower than dry weight (Galgan and Frank 1995). Values originally referred to in parts per million are reported here as milligrams per liter, while the occasional value reported as milligrams per liter is given as reported in the original. For whole blood, values less than $0.040-0.050 \mathrm{mg} / \mathrm{L}$ result in nutritional muscular dystrophy in livestock (Flueck 1994 and references therein). Puls (1994) provided reference values of $0.080-0.500 \mathrm{mg} / \mathrm{L}$ plasma. When compared to livestock standards, the levels of Se in wildlife and wildlife forage have often been reported as deficient. Table 1 summarizes the wildlife Se values reported in the examples in the following discussion and in additional studies.

\section{Suggested selenium reference values}

There are no standard recommended values for Se in wildlife. The minimum domestic stock liver recommendations are 0.120 (Van Metre and Callan 2001) to $0.150 \mathrm{mg} / \mathrm{kg}$ (ww) (Galgan and Frank 1995), and $0.063 \mathrm{mg} / \mathrm{kg}$ (ww) was reported as critically low by McDowell et al. (1995). Puls (1994) recommended criteria of deficiency when liver $\mathrm{Se}<0.15 \mathrm{mg} / \mathrm{kg}$ (ww), $0.15-0.22 \mathrm{mg} / \mathrm{kg}$ (ww) as marginal, and $>0.22 \mathrm{mg} / \mathrm{kg}$ (ww) as optimal in cattle. Pollock (2005) concluded that $0.150 \mathrm{mg} / \mathrm{kg}$ (ww) liver represented deficiency in white-tailed deer, and values $<0.050 \mathrm{mg} / \mathrm{kg}$ (ww) are considered severely deficient by the National Veterinary Council of Sweden (Galgan and Frank 1995). Wilson and Grace (2001) reported that young red deer (Cervus elaphus) with WMD had liver Se concentrations $<0.035 \mathrm{mg} / \mathrm{kg}$ (ww).

\section{Scandinavia}

In examples from Scandinavia, Vikøren et al. (2005) reported a mean liver concentration of $0.110 \mathrm{mg} / \mathrm{kg}$ (ww) for 245 hunter-killed Norwegian red deer, while Galgan and Frank (1995) reported a mean of $0.250 \mathrm{mg} / \mathrm{kg}$ (ww) and with a median of $0.150 \mathrm{mg} / \mathrm{kg}$ (ww) for 2,080 Swedish moose (Alces alces). The mean reported values are frequently higher than the median values as a handful of individuals from any sample often have exceptionally high Se concentrations. These means are marginally adequate to deficient levels based on the standards above. Norwegian moose had a mean liver Se of $0.468 \mathrm{mg} / \mathrm{kg}$ (ww), reindeer (Rangifer tarandus) had $0.218 \mathrm{mg} / \mathrm{kg}$ (ww), and roe deer (Capreolus capreolus) had $0.168 \mathrm{mg} / \mathrm{kg}$ (ww), reflecting a concentration gradient due to the greater aerial deposition of the element in coastal areas (Vikøren et al. 2011). This study also found that an inland moose population with compromised condition and reduced productivity had deficient $\mathrm{Se}$ levels, with some individuals having liver concentrations below the detection limit. The environmental conditions that lead to a higher coastal deposition of airborne Se are discussed later; however, it can be seen that populations may exist along a gradient from source to sink areas (Flueck and Smith-Flueck 2011a). In another example, Frøslie et al. (1984) reported that moose liver values ranged from 0.080 to $0.92 \mathrm{mg} / \mathrm{kg}$ (ww), depending on concentrations in moss and the levels of aerial deposition. Although $50-60 \%$ of the sampled Swedish moose fell below $0.100 \mathrm{mg} / \mathrm{kg}$ (ww) of liver (Galgan and Frank 1995; Pollock 2005), these populations did not display clinical signs of deficiency. 
Table 1 Selenium status for wild, unsupplemented herbivores

\begin{tabular}{|c|c|c|c|c|c|}
\hline Species & Locality & $N$ & Conc. & Indications & Reference \\
\hline \multicolumn{6}{|l|}{ Liver (mg/kg, ww) } \\
\hline \multicolumn{6}{|c|}{ Suggested reference values: $<0.15$, deficient; $0.15-0.22$, marginal; $>0.22$, adequate } \\
\hline Red deer & Norway & 245 & $0.11 \pm 0.09$ & $\mathrm{nr}$ & Vikøren et al. (2005) \\
\hline Red deer & Norway & & 0.20 & $\mathrm{nr}$ & Frøslie et al. (1984) \\
\hline Red deer & Poland & 73 & $0.09 \pm 0.08^{\mathrm{c}}$ & $\mathrm{nr}$ & Pilarczyk et al. (2009) \\
\hline Red deer & Poland & 23 & $0.095 \pm 0.018$ & $\mathrm{nr}$ & Pilarczyk et al. (2011b) \\
\hline Red deer & Poland & 20 & $0.063 \pm 0.033$ & $\mathrm{ch}$ & Jarzyńska and Falandysz (2011) \\
\hline Red deer & Croatia & 19 & $0.241 \pm 0.053$ & $\mathrm{nr}$ & Lazarus et al. (2008) \\
\hline Elk & WA, USA & 9 & $0.070 \pm 0.066$ & $\mathrm{nr}$ & Fielder (1986) \\
\hline Moose & Sweden & 2,080 & $0.250 \pm 0.288$ & $\mathrm{nr}$ & Galgan and Frank (1995) \\
\hline Moose & Norway & 422 & $0.47 \pm 0.69$ & $\mathrm{nr}$ & Vikøren et al. (2011) \\
\hline Moose & Norway & & 0.42 & $\mathrm{nr}$ & Frøslie et al. (1984) \\
\hline Moose $^{a}$ & Norway & 57 & 1.20 & $\mathrm{nr}$ & Ytrehus et al. (1999) \\
\hline Moose $^{a}$ & Norway & 63 & 0.13 & $\mathrm{nr}$ & Ytrehus et al. (1999) \\
\hline Moose & MN USA & & & & \\
\hline ag habitat & & 47 & $0.68^{\mathrm{c}}$ & $\mathrm{dp}$ & Custer et al. (2004) \\
\hline Bog/forest & & 32 & $0.30^{\mathrm{c}}$ & $\mathrm{dp}$ & Custer et al. (2004) \\
\hline Roe deer & Poland & 96 & $0.16 \pm 0.14^{\mathrm{c}}$ & $\mathrm{nr}$ & Pilarczeyk et al. (2009) \\
\hline Roe deer-spring & Poland & 17 & $0.08 \pm 0.03$ & $\mathrm{nr}$ & Pilarczeyk et al. (2011a) \\
\hline Roe deer-winter & Poland & 21 & $0.05 \pm 0.02$ & $\mathrm{nr}$ & Pilarczeyk et al. (2011a) \\
\hline Roe deer-male & Poland & 10 & $0.093 \pm 0.025$ & $\mathrm{nr}$ & Pilarczeyk et al. (2011a) \\
\hline Roe deer-female & Poland & 13 & $0.097 \pm 0.027$ & $\mathrm{nr}$ & Pilarczeyk et al. (2011a) \\
\hline Roe deer & Germany & 11 & $0.27 \pm 0.07$ & $\mathrm{nr}$ & Humann-Ziehank et al. (2008) \\
\hline Roe deer & Norway & 280 & $0.17 \pm 0.14$ & $\mathrm{nr}$ & Vikøren et al. (2011) \\
\hline Reindeer & Norway & 73 & $0.21 \pm 0.07$ & $\mathrm{nr}$ & Vikøren et al. (2011) \\
\hline Reindeer & Norway & & 0.50 & $\mathrm{nr}$ & Frøslie et al. (1984) \\
\hline Reindeer/caribou & Greenland & 126 & 0.253 & $\mathrm{nr}$ & Aastrup et al. (2000) \\
\hline Mule deer & WA, USA & 10 & $0.121 \pm 0.057$ & $\mathrm{nr}$ & Fielder (1986) \\
\hline Mule deer & SD, USA & 38 & $0.64 \pm 0.05$ & $\mathrm{ch}$ & Zimmerman et al. (2008) \\
\hline White-tailed deer & MI, USA & 8 & $0.24 \pm 0.02$ & $\mathrm{nr}$ & Brady et al. (1978) \\
\hline White-tailed deer & FL, USA & 139 & $0.191^{\mathrm{c}}$ & $\mathrm{nr}$ & McDowell et al. (1995) \\
\hline White-tailed deer & $\mathrm{SD}, \mathrm{USA}$ & 42 & $0.81 \pm 0.05$ & $\mathrm{ch}$ & Zimmerman et al. (2008) \\
\hline White-tailed deer & VA, USA & 60 & $0.08 \pm 0.03$ & id & Sleeman et al. 2009, (2010) \\
\hline Pronghorn adult & OR, USA & 17 & $0.12 \pm 0.03$ & $\mathrm{pr}$ & Dunbar et al. (1999) \\
\hline Pronghorn & ID, USA & $55^{\mathrm{b}}$ & $0.13 \pm 0.04^{\mathrm{c}}$ & wfs & Stoszek et al. (1980) \\
\hline Pronghorn & MT, USA & $55^{\mathrm{b}}$ & $0.30 \pm 0.05^{\mathrm{c}}$ & $\mathrm{nr}$ & Stoszek et al. (1980) \\
\hline Mt. goat & WA, USA & 10 & $0.022 \pm 0.020$ & $\mathrm{nr}$ & Fielder (1986) \\
\hline Sheep & NV, USA & 38 & $0.173 \pm 0.029$ & $\mathrm{~cm}$ & Cox (2006) \\
\hline Wild boar & Poland & 172 & $0.190 \pm 0.09$ & $\mathrm{nr}$ & Pilarczeyk et al. (2010) \\
\hline
\end{tabular}

\section{$\operatorname{Blood}(\mathrm{mg} / \mathrm{L})$}

Suggested reference values: $<0.05$, blood extremely deficient; $0.08-0.50$, plasma adequate

$\begin{array}{llrlll}\text { Elk } & \text { WA, USA } & 118 & 0.086 & \mathrm{nr} & \text { Hein et al. (1994) } \\ \text { Moose } & \text { AK, USA } & 20 & 0.12 \pm 0.013 & \mathrm{nr} & \text { Stephenson et al. (2001) } \\ \text { Moose } & \text { AK, USA } & 22 & 0.12 \pm 0.03 & \mathrm{pr} & \text { O’Hara et al. (2001) } \\ \text { Moose } & \text { WA, USA } & 2 & 0.015 & \mathrm{nr} & \text { Hein et al. (1994) } \\ \text { Mule deer } & \text { WA, USA } & 6 & 0.081 & \mathrm{nr} & \text { Hein et al. (1994) } \\ \text { Black-tailed deer } & \text { CA, USA } & 135 & 0.037 \pm 0.030 & \mathrm{pr} & \text { Flueck (1994) } \\ \text { Black-tailed deer } & \text { CA, USA } & 10 & 0.089 & \mathrm{pr} & \text { Pine and Mansfield (1983) }\end{array}$


Table 1 (continued)

\begin{tabular}{|c|c|c|c|c|c|}
\hline Species & Locality & $N$ & Conc. & Indications & Reference \\
\hline Mule deer-resident & CA, USA & 563 & $0.103 \pm 0.1$ & $\mathrm{nr}$ & Oliver et al. (1990) \\
\hline Mule deer - migratory & CA, USA & 1,132 & $0.081 \pm 0.067$ & $\mathrm{nr}$ & Oliver et al. (1990) \\
\hline Mule deer-resident & CA, USA & 69 & 0.084 & $\mathrm{nr}$ & Dierenfeld and Jessup (1990) \\
\hline Mule deer - migratory & CA, USA & 82 & 0.054 & $\mathrm{nr}$ & Dierenfeld and Jessup (1990) \\
\hline Pronghorn & OR USA & & & & \\
\hline Neonate & Year 1 & 17 & $0.085 \pm 0.021$ & $\mathrm{pr}$ & Dunbar et al. (1999) \\
\hline Neonate & Year 2 & 44 & $0.051 \pm 0.015$ & $\mathrm{pr}$ & Dunbar et al. (1999) \\
\hline Adult & & 20 & $0.099 \pm 0.036$ & $\mathrm{pr}$ & Dunbar et al. (1999) \\
\hline Mt. goat & WA, USA & 20 & $0.035 \pm 0.025$ & $\mathrm{nr}$ & Fielder (1986) \\
\hline Mt. goat & WA, USA & 11 & $0.057 \pm 0.056$ & $\mathrm{nr}$ & Fielder (1986) \\
\hline Mt. goat & WA, USA & 19 & $0.041 \pm 0.032$ & $\mathrm{nr}$ & Robbins et al. (1985) \\
\hline Mt. goat & Alberta, CA & 7 & $0.150 \pm 0.110$ & $\mathrm{nr}$ & Samson et al. (1989) \\
\hline Sheep & Alberta, CA & 51 & $0.025 \pm 0.011$ & $\mathrm{nr}$ & Samson et al. (1989) \\
\hline Sheep & Alberta, CA & 8 & $0.120 \pm 0.030$ & $\mathrm{nr}$ & Samson et al. (1989) \\
\hline Sheep & WA, USA & 13 & $0.09 \pm 0.06$ & $\mathrm{nr}$ & Coggins (2006) \\
\hline Sheep & WA, USA & 16 & $0.19 \pm 0.09$ & $\mathrm{nr}$ & Coggins (2006) \\
\hline Sheep & WA, USA & 17 & $0.21 \pm 0.07$ & $\mathrm{nr}$ & Coggins (2006) \\
\hline Sheep & WA, USA & 14 & 0.084 & pr & Hein et al. (1994) \\
\hline Sheep & OR, USA & 27 & $0.11 \pm 0.07$ & $\mathrm{nr}$ & Coggins (2006) \\
\hline Sheep & OR, USA & 25 & $0.11 \pm 0.08$ & $\mathrm{nr}$ & Coggins (2006) \\
\hline Sheep & WY, USA & 43 & 0.130 & $\mathrm{pr}$ & Hinilicka et al. (2004) \\
\hline \multicolumn{6}{|c|}{ Skeletal muscle (mg/kg, ww) } \\
\hline Red deer & Poland & 20 & $0.043 \pm 0.025$ & $\mathrm{ch}$ & Jarzyńska and Falandysz (2011) \\
\hline Red deer & Croatia & 34 & $0.531 \pm 0.091$ & $\mathrm{nr}$ & Lazarus et al. (2008) \\
\hline White-tailed deer & MI, USA & 109 & $0.04 \pm 0.016^{\mathrm{c}}$ & $\mathrm{nr}$ & Ullrey et al. (1981) \\
\hline White-tailed deer & MI, USA & 8 & $0.07 \pm 0.01$ & $\mathrm{nr}$ & Brady et al. (1978) \\
\hline Reindeer/caribou & Greenland & 127 & 0.104 & $\mathrm{nr}$ & Aastrup et al. (2000) \\
\hline \multicolumn{6}{|l|}{ Serum $(\mathrm{mg} / \mathrm{L})$} \\
\hline White-tailed deer & FL, USA & 174 & $0.013 \pm 0.001^{\mathrm{c}}$ & $\mathrm{nr}$ & McDowell et al. (1995) \\
\hline White-tailed deer & MI, USA & 32 & $0.11 \pm 0.005$ & $\mathrm{nr}$ & Brady et al. (1978) \\
\hline Pronghorn & OR, USA & 20 & $0.049 \pm 0.010$ & $\mathrm{pr}$ & Dunbar et al. (1999) \\
\hline \multicolumn{6}{|l|}{ Hair (mg/kg) } \\
\hline Elk & OR, USA & 8 & $0.110 \pm 0.06$ & $\mathrm{nr}$ & Fielder (1986) \\
\hline Moose & AK, USA & 23 & $0.50 \pm 0.20$ & $\mathrm{pr}$ & O’Hara et al. (2001) \\
\hline Mule deer & OR, USA & 10 & $0.150 \pm 0.08$ & $\mathrm{nr}$ & Fielder (1986) \\
\hline Mt. goat & OR, USA & 22 & $0.020 \pm 0.023$ & $\mathrm{nr}$ & Fielder (1986) \\
\hline Mt. goat & OR, USA & 6 & $0.070 \pm 0.021$ & $\mathrm{nr}$ & Fielder (1986) \\
\hline
\end{tabular}

Values are as originally reported or the means of pooled reported values. Reference values are suggested based on the discussion in this review $c h$ clinically healthy, $\mathrm{cm}$ high incidence of capture myopathy, $d p$ declining population, $n r$ none reported, $p r$ poor recruitment, $w f s$ weak fawn syndrome, id immune depression and disease

${ }^{a}$ Median rather than mean values

${ }^{\mathrm{b}}$ Combined Idaho and Montana sample sizes $=55$

${ }^{\mathrm{c}}$ Values converted from dry weight 


\section{Europe}

Elsewhere in Europe, roe deer in northern Germany were reported to have mean liver Se concentrations similar to those of domestic sheep of $0.270 \mathrm{mg} / \mathrm{kg}$ (ww), although their vitamin E levels were higher (Humann-Ziehank et al. 2008). Seventy-three red deer and 96 roe deer sampled in Poland from 2003 to 2007 had mean liver Se levels of 0.090 and $0.160 \mathrm{mg} / \mathrm{kg}$ (ww), respectively, all without reported clinical signs (Pilarczyk et al. 2009). Kidney concentrations were higher. Polish wild boars (Sus scofra) also had higher concentrations in kidney than in liver, with the mean of 172 liver values being $0.190 \mathrm{mg} / \mathrm{kg}$ (ww) and with spring values being higher than autumn (Pilarczyk et al. 2010). In continued work, Pilarczyk et al. (2011b) also demonstrated a correlation between liver Se and GPX activity $\left(r^{2}=0.73\right)$.

\section{North American mountain goats and bighorn sheep}

High-elevation populations of mountain goats and wild sheep may be especially susceptible to Se deficiency. In North America, Fielder (1986) found that Washington mountain goats (Oreamnos americanus) had deficient mean liver Se levels of $0.022 \mathrm{mg} / \mathrm{kg}$ as compared to elk $(C$. elaphus) of $0.070 \mathrm{mg} / \mathrm{kg}$ and mule deer (Odocoileus hemionus) of $0.121 \mathrm{mg} / \mathrm{kg}$, both from lower altitudes. Unfortunately, Fielder et al. (1986) did not report whether the liver samples were analyzed on a wet weight basis, although the values reported probably reflect wet weight analysis. Goat forage species were also analyzed for $\mathrm{Se}$ content, with the highest concentration reported at $0.030 \mathrm{mg} / \mathrm{kg}$ and with most falling below the detection limit, again reflecting the gradients of $\mathrm{Se}$ found in the environment. Hair sampling results were reported as $0.070 \mathrm{mg} / \mathrm{kg}$ for goats, $0.110 \mathrm{mg} / \mathrm{kg}$ for elk, and $0.150 \mathrm{mg} / \mathrm{kg}$ for deer. When we plotted the mean liver vs. mean hair

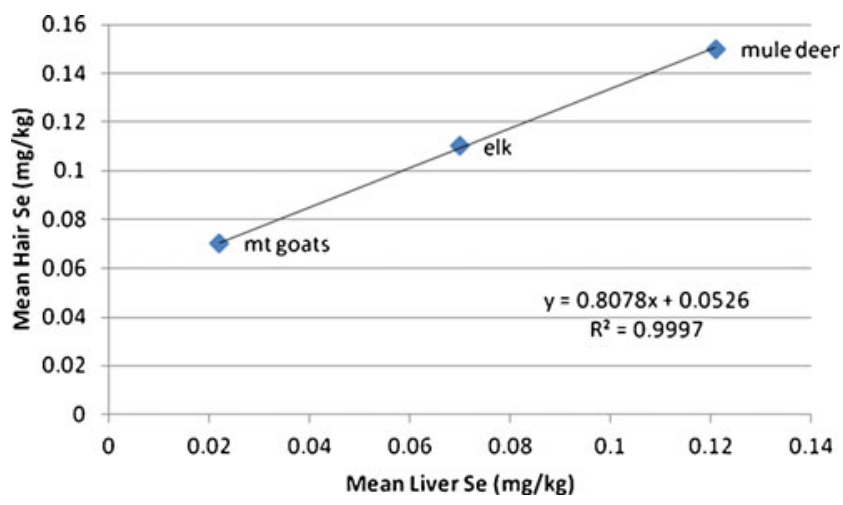

Fig. 1 Mean hair vs. mean liver Se concentrations of Table 2 in Fielder et al. (1986). The samples were from hunter-killed animals, with sample size ranging from $n=6$ for hair from goats to $n=10$ for hair from deer and liver from goats and deer concentrations of Fielder et al. (1986), an excellent correlation was obtained, although the data set is admittedly limited. However, this suggests that hair sampling may provide a non-intrusive method for establishing the Se status of wild populations. It must be cautioned that external Se contamination on hair is not easily removed by washing prior to analysis (Morton et al. 2002). This is shown in Fig. 1, and it suggests that more work in this area would be valuable. Blood concentrations were not correlated with liver Se in those data.

White muscle disease was reported in British Columbia mountain goats following capture-related stress by Hebert and Cowan (1971b). These animals were not sampled for their Se content; however, they used forage species containing $<0.050 \mathrm{mg} / \mathrm{kg}$ Se. In Nevada, Cox (2006) reported that hunter-harvested bighorn sheep (Ovis canadensis) mean liver Se ranged from 0.168 to $0.177 \mathrm{mg} / \mathrm{kg}$. Although not specified in that report, these are probably wet weight values, and supplementation with mineral blocks did not raise this value above $0.203 \mathrm{mg} / \mathrm{kg}$, perhaps suggesting that they were adequate. These levels are within the marginal range for cattle; however, many wildlife populations with lower values have been reported (Table 1). Robbins et al. (1985) established a linear relationship between whole-blood Se levels and GPX activity in Olympic National Park, Washington, mountain goats. Selenium in blood averaged $0.041 \mathrm{mg} / \mathrm{L}$ for 19 goats, although this value was heavily influenced by one high result of $0.147 \mathrm{mg} / \mathrm{L}$. Interestingly, the GPX activity per unit Se was higher for goats than for domestic cattle, suggesting that goats are adapted to a low Se environment and have a lower physiological requirement for the element. Goats injected with Se supplements required up to 30 days to develop peak GPX activity. In contrast, Samson et al. (1989) were not able to demonstrate that GPX activity per unit Se was higher in bighorn sheep or mountain goats than for cattle.

In Alberta bighorn sheep and mountain goats, 51 sheep had low whole-blood levels of $0.025 \mathrm{mg} / \mathrm{L}$ Se with a range of 0.005-0.045 mg/L at Ram Mountain, and eight sheep had $0.120 \mathrm{mg} / \mathrm{L}$ with a range of $0.070-0.160 \mathrm{mg} / \mathrm{L}$ at Mount Allan (Samson et al. 1989). For comparison, five captive sheep maintained on an adequate Se diet had an adequate mean concentration of $0.112 \mathrm{mg} / \mathrm{L}$, with a range of 0.090 $0.120 \mathrm{mg} / \mathrm{L}$. In the same report, mountain goats at Caw Ridge, Alberta, had mean blood Se of $0.150 \mathrm{mg} / \mathrm{L}$ over a range of $0.069-0.330 \mathrm{mg} / \mathrm{L}$. Although the sheep population at Ram Mountain would be considered deficient compared to livestock, once again, no clinical signs of WMD were discernible. In an Oregon sheep population, Se supplementation via salt was provided on the Lostine winter range (Coggins 2006). Since 1977, whole-blood Se levels in this population were the highest of all populations tested in the region, with an average of $0.390 \mathrm{mg} / \mathrm{L}$ for the period 1997-2005. Neighboring herds 
ranged from $0.090 \mathrm{mg} / \mathrm{L}$ at Asotin, Washington, to $0.210 \mathrm{mg} /$ $\mathrm{L}$ at Redbird, Idaho. Lostine range lamb survival was better than in the other nearby populations. Similarly, Hnilicka et al. (2004) reported improved recruitment in Se-supplemented bighorn sheep in Wyoming, while Dean et al. (2004) reported that Wyoming bighorn lambs in captivity showed a decrease from 0.190 to $0.120 \mathrm{mg} / \mathrm{L}$ whole-blood Se when maintained on a diet containing $0.020-0.030 \mathrm{mg} / \mathrm{kg}$ Se for 2.5 months. Their GPX activity also decreased; however, no clinical signs of deficiency were identified. Meanwhile, Rosen et al. (2009) reported an absence of benefit to Se supplementation of captive bighorn sheep. However, these captive sheep already had serum Se values of $0.180-0.450 \mathrm{mg} / \mathrm{L}$, within the range considered adequate. Mincher et al. (2008) documented bighorn sheep leaving normal summer range to make bimonthly 26$\mathrm{km}, 2,000-\mathrm{m}$ elevation round-trip migrations, with the purpose of visiting Se-containing mineral licks on normal winter range. Also drawn by sodium chloride, this geophagia supplemented a summer range diet which was deficient in Se.

\section{White-tailed deer}

Among other North American studies, 139 white-tailed deer in southern Florida had a mean liver Se concentration of $0.169 \mathrm{mg} / \mathrm{kg}$ (ww), with a range of $0.035-1070 \mathrm{mg} / \mathrm{kg}$ (ww) over 4 years of sampling. Thirteen percent of these deer were considered critically deficient and another $55 \%$ were marginal (McDowell et al. 1995). The wide range in individual values is not uncommon, and the authors commented that "some deer either live in pockets of habitat that supply substantially more selenium...or they may exhibit different feeding behavior." As often reported, kidney Se levels were higher than for liver, but not correlated to liver Se, and liver is thought to respond more quickly to dietary changes in Se (Oh et al. 1976). When we plotted the mean serum Se data reported by McDowell et al. (1995) vs. their mean liver concentrations from seven deer populations, a linear correlation with $r^{2}=0.77$ was obtained. This suggests that both blood and liver Se are better indicators than kidney for assessing animal status.

Ullrey et al. (1981) reported that muscle Se concentrations with a mean value of $0.040 \mathrm{mg} / \mathrm{kg}$ (ww) and a range of $0.013-0.123 \mathrm{mg} / \mathrm{kg}$ (ww) were considered deficient in $92 \%$ of Michigan white-tailed deer as compared to domestic animals that were demonstrably deficient. Comparing several ungulate species in Washington, Hein et al. (1994) found that Washington bighorn sheep, mule deer, and some elk populations were marginal in whole-blood Se, while moose were reported to be severely deficient at $0.015 \mathrm{mg} / \mathrm{L}$; however, the moose sample size was very small at $n=2$.

\section{Black-tailed deer}

Flueck (1991) found a linear relationship $\left(r^{2}=0.91\right)$ between whole-blood Se levels and GPX activity in black-tailed deer (Odocoileus hemionus columbianus) in California. Selenium levels in unsupplemented wild deer ranged from 0.009 to $0.119 \mathrm{mg} / \mathrm{L}$, while deer supplemented with oral boluses had levels ranging from 0.020 to $0.307 \mathrm{mg} / \mathrm{L} \mathrm{Se}$ in whole blood. It was also reported that supplementing wild black-tailed deer with initial whole-blood Se concentrations below $0.050-0.100 \mathrm{mg} / \mathrm{L}$ increased fawn survival over twofold (Flueck et al. 1989; Flueck 1994). In continued California work, Oliver et al. (1990) sampled 1,695 mule deer from 15 geographically distinct herds for whole-blood Se. They reported that one third of these groups had median blood Se levels $<0.05 \mathrm{mg} / \mathrm{L}$ and that individual deer were found to have a concentration less than the detection limit of $0.01 \mathrm{mg} / \mathrm{L}$. Migratory deer, which utilized high-elevation range during summer, had lower overall levels than resident deer. Dierenfeld and Jessup (1990) also reported lower blood Se for non-migratory deer, although their vitamin $\mathrm{E}$ levels were higher.

In contrast to Flueck (1989, 1994), Brady et al. (1978) reported that supplementation of white-tailed deer with a diet containing $0.200 \mathrm{mg} / \mathrm{kg} \mathrm{Se}$, which had been previously subsisting on a usual diet containing only $0.040 \mathrm{mg} / \mathrm{kg} \mathrm{Se}$, did not improve juvenile mortality rates, although vitamin E supplementation did. However, serum Se levels at the onset of the experiment were in the range $0.110-0.120 \mathrm{mg} / \mathrm{L} \mathrm{Se}$, which may not be deficient, and liver values were $0.240 \mathrm{mg} / \mathrm{kg}$ (ww), higher than in many other deer populations.

Impaired reproduction in moose, elk, and black-tailed deer

In a study of poor neonatal survival and adult mortality of Alaskan moose, particularly females were found deficient in Se (O'Hara et al. 2001; Stephenson et al. 2001). O'Hara et al. (2001) considered whole-blood levels with a mean of $0.120 \mathrm{mg} / \mathrm{L} \mathrm{Se}$ as marginal, for 22 animals sampled. Hair was also sampled in this study, with a value of $0.500 \mathrm{mg} / \mathrm{kg}$ (ww) for 23 females and $0.900 \mathrm{mg} / \mathrm{kg}$ (ww) for nine males. A minimum recommended level for cattle hair of $0.500 \mathrm{mg}$ / kg (ww) was given by Puls (1994). Stephenson et al. (2001) reported mean whole-blood $\mathrm{Se}$ in Tanana Flats moose of $0.120 \mathrm{mg} / \mathrm{L}$, with 8 of the 20 animals sampled having $<0.085 \mathrm{mg} / \mathrm{L}$, while captive moose that displayed symptoms of WMD had whole-blood Se levels of $0.160 \mathrm{mg} / \mathrm{L}$, but critically low levels of vitamin E. These authors concluded that neonatal moose losses due to Se/vitamin E deficiency were often unrecognized. Starkley et al. (1982) speculated that the low reproductive performance of Roosevelt elk (Cervus elaphus roosevelti) stemmed from Se deficiency 
since domestic livestock in their range require Se supplementation. Similarly, Pine and Mansfield (1983) reported a mean whole-blood Se concentration of $0.89 \mathrm{mg} / \mathrm{L}$ with a range of $0.013-0.247 \mathrm{mg} / \mathrm{L}$ for 12 black-tailed deer in California, for a herd with poor recruitment.

\section{American pronghorn}

Selenium levels in pronghorn (Antilocapra americana) from a declining herd in Oregon were determined to be mostly marginal to low in Se content, with nine males in the fall of 1996 having a range of $0.06-0.22 \mathrm{mg} / \mathrm{kg}$ (ww), with a mean of $0.11 \mathrm{mg} / \mathrm{kg}$ (ww) in the liver, and does in the spring of 1997 having a range of $0.10-0.15 \mathrm{mg} / \mathrm{kg}$ (ww) and a mean of $0.13 \mathrm{mg} / \mathrm{kg}$ (ww) (Dunbar et al. 1999). These animals also showed no signs of clinical deficiency, which the authors attributed to adequate spring serum levels of vitamin $\mathrm{E}$ in the does. For comparison, Raisbeck et al. (1996) reported that four captive pronghorns maintained on feed containing $0.300 \mathrm{mg} / \mathrm{kg}$ Se had mean concentrations of $0.50 \mathrm{mg} / \mathrm{kg}$ (ww) in the liver, $0.67 \mathrm{mg} / \mathrm{kg}$ (ww) in the kidney, and $0.21 \mathrm{mg} / \mathrm{kg}(\mathrm{ww})$ in skeletal muscle. In central Idaho, pronghorn Se levels in a struggling herd were compared to levels in a healthy Montana herd. Liver Se in Idaho averaged $0.13 \pm 0.04 \mathrm{mg} / \mathrm{kg}$ (ww), and a minimum of $\sim 20 \%$ of neonate fawns showed evidence of "weak fawn syndrome" (Bodie and O'Gara 1980; Stoszek et al. 1980). Only $45 \mathrm{~km}$ to the east in Montana, pronghorn fawns had considerably higher survival rates, and liver Se averaged $0.30 \pm 0.05 \mathrm{mg} / \mathrm{kg}$ (ww).

\section{Patagonian huemul}

In South America, the 20-year general lack of recovery of Patagonian huemul deer (Hippocamelus bisulcus) was hypothesized to be due to $\mathrm{Se}$ and iodine deficiencies based on low antler quality compared to the past, a high prevalence of osteopathy among adults, low recruitment rates, and overt Se deficiency in neighboring Chile (Flueck and Smith-Flueck 2011b). Among young adult Patagonian huemul deer, a conservative prevalence of osteopathy of $52 \%$, with a specific physiognomy of chronic alveolar osteomyelitis and osteoarthritis, suggested that Se-iodine deficiency was a prime etiological factor (Flueck and Smith-Flueck 2008). Se deficiency in that region is likely more prevalent in high-altitude refugia occupied by remnant populations of endangered huemul. Importantly, the inaccessibility of most traditional winter ranges and valley bottoms, elimination of migratory traditions, and concomitant elimination of source populations were suggested to contribute to current poor huemul recruitment.

\section{African elephants}

Africa provides another example of probable Se and iodine deficiency induced by habitat loss (Milewski 2002). Knysna elephants (Loxodonta africana) living near Cape Town were previously able to balance their nutrition by foraging over a large geographic range. However, their confinement to forests and fynbos seems to have prevented them from acquiring the micronutrients required for pregnancy and lactation. Seaweed cast up after storms originally provided the necessary iodine and Se, but Knysna elephants no longer have access to the shores. Analyzing large mineral licks used by herbivores in Tanzania, Mills and Milewski (2007) found Se concentrations to be much higher than in topsoils and suggested that animals may use the taste of sodium chloride as a clue to such zones where they are likely to find greater quantities of micronutrients, including Se. This finding is in agreement with that for bighorn sheep discussed above (Mincher et al. 2008).

Selenium deficiency in captive animals, capture myopathy, and other clinical cases

Selenium deficiency has frequently been reported among captive wildlife populations. With the advent of deer farming, Se-responsive unthriftiness in red deer and mortality rates in fallow deer (Dama dama) have been reported (Van Reenen 1980; Knox et al. 1987; Von Kerckerinck zur Borg 1987). Grace and Wilson (2002) reported that young red deer with extremely low liver Se concentrations of 0.002 $0.009 \mathrm{mg} / \mathrm{kg}(\mathrm{ww})$ exhibited WMD and that there was a linear relationship between liver and blood Se concentrations $\left(r^{2}=0.86\right)$. A higher incidence of post-capture myopathy occurred in New Zealand red deer caught in Se-deficient areas, and WMD as well as Se-responsive symptoms such as ill thrift were observed in adult deer and fawns (Van Reenen 1980). Some reports have described overt symptoms of WMD in fallow deer, red deer, and Pere David's deer (Elaphurus davidianus; Alexander 1986). Matzke (1986) reported the prevention of necrobacillosis in fawns with $\mathrm{Se}$ and vitamin $\mathrm{E}$ treatment. A trial in red deer showed a linear relationship between blood Se and GPX. In that study, both periodic oral dosing with Se or a single injection of barium selenate significantly elevated blood Se and GPX levels throughout the trials (Mackintosh et al. 1989). These reports are similar to those initially reported in domestic lambs and calves (Muth 1955) and deer (Hadlow 1955). White muscle disease, accompanied by decreased immune function and susceptibility to disease, was also reported for lesser kudu (Tragelaphus imberbus) at the Basle Zoo (Switzerland) as compared to Se/vitamin E-supplemented kudu at the Stuttgart Zoo (Germany) (Besselmann et al. 2008). However, the Se levels in these animals were not reported. 
Clinical signs including WMD have been documented in juvenile and adult captive reindeer and other ruminants: adverse effects of deficiency included failure to conceive, stillbirths, neonatal deaths, low birth weights, retarded growth, and lameness (National Zoological Park 1972, 1974; Griner 1978; National Research Council 1983). Sleeman et al. (2009) suggested that Se deficiency may have contributed to the development of paratuberculosis in whitetailed deer, with all deer considered having marginal or deficient hepatic Se levels (mean $=0.086 \pm 0.03 \mathrm{mg} / \mathrm{kg}$, ww), which may also have predisposed this population to the development of a parasitism/malnutrition syndrome (Sleeman et al. 2010). Finally, Yoshioka et al. (2000) reported hepatic lesions and cardiomyopathy similar to the human Se deficiency Keshan disease in Se-deficient farmed Sika deer (Cervus nippon). Of 25 Sika deer sampled, 18 had serum Se concentration less than the detection limit of $0.025 \mathrm{mg} / \mathrm{L}$.

As seen from the foregoing discussion and in Table 1, many sampled wild populations have deficient or even seriously deficient Se status by comparison to livestock. However, overt symptoms of deficiency have only been occasionally described, possibly due to the difficulties of monitoring wild animals. While wildlife may have lower physiological requirements than livestock, this has not been conclusively demonstrated. Subclinical deficiencies in wild populations are especially difficult to recognize and may be common. Establishing a reference range, particularly regarding subclinical situations, requires production response trials which would thus also include all factors interacting in the absolute mineral requirement. In the next section, the factors that affect the amount and bioavailability of Se in the natural environment, and thus the amount in forage plants used by wildlife, are examined.

Selenium in the environment

\section{Selenium as a component of habitat}

Selenium can exist in four species, each of which has unique chemical behavior. As a chemical analog of sulfur, the reduced species selenide is often found as a contaminant of sulfide ores, such as pyrite or galena. These selenides $\left(\mathrm{Se}^{2-} / \mathrm{HSe}^{-}\right)$are non-bioavailable forms of the element found in parent rocks. Oxidation of selenides by exposure to air creates higher oxidation states and increases the bioavailability of the element. Elemental selenium $\left(\mathrm{Se}^{0}\right)$ is first produced (Thompson et al. 1956), and continued oxidation results in selenite $\left(\mathrm{HSeO}_{3}{ }^{-} / \mathrm{SeO}_{3}{ }^{2-}\right.$ or $\left.\mathrm{Se}^{\mathrm{IV}}\right)$ and, eventually, selenate $\left(\mathrm{SeO}_{4}{ }^{2-}\right.$ or $\mathrm{Se}^{\mathrm{VI}}$; Geering et al. 1968; Lakin 1972; Elrashidi et al. 1987). The presence of certain minerals or anaerobic bacteria may reduce and sorb Se (Maiers et al.
1988; Oremland et al. 1989, 1994; Myneni et al. 1997; Refait et al. 2000). However, microbial oxidizers are also known (Sarathchandra and Watkinson 1981), and a variety of mechanisms compete to establish the predominant species in an environmental setting. Available selenate and selenite taken up by plants provide the traces needed by foraging wildlife as an essential nutrient.

Although natural systems are seldom at equilibrium, the species of Se in soil will tend toward the predicted species in Fig. 2 with time (Geering et al. 1968). The regions in Fig. 2 were calculated based on thermodynamic considerations that have been confirmed by field measurements (Kubota and Cary 1982; van Dorst and Peterson 1984; Masscheleyn et al. 1990; Mincher et al. 2007). Figure 2 shows that oxidizing (dry) alkaline soil favors the available selenate and selenite species, while reducing (wet) acidic soil favors unavailable elemental Se and selenides. Low redox potentials occur in soil inundated with stagnant water, resulting in oxygen depletion and Se reduction (Yang et al. 2006; Mincher et al. 2007). For example, Gil et al. (2004) reported that low forage and deficient bovine serum $\mathrm{Se}$

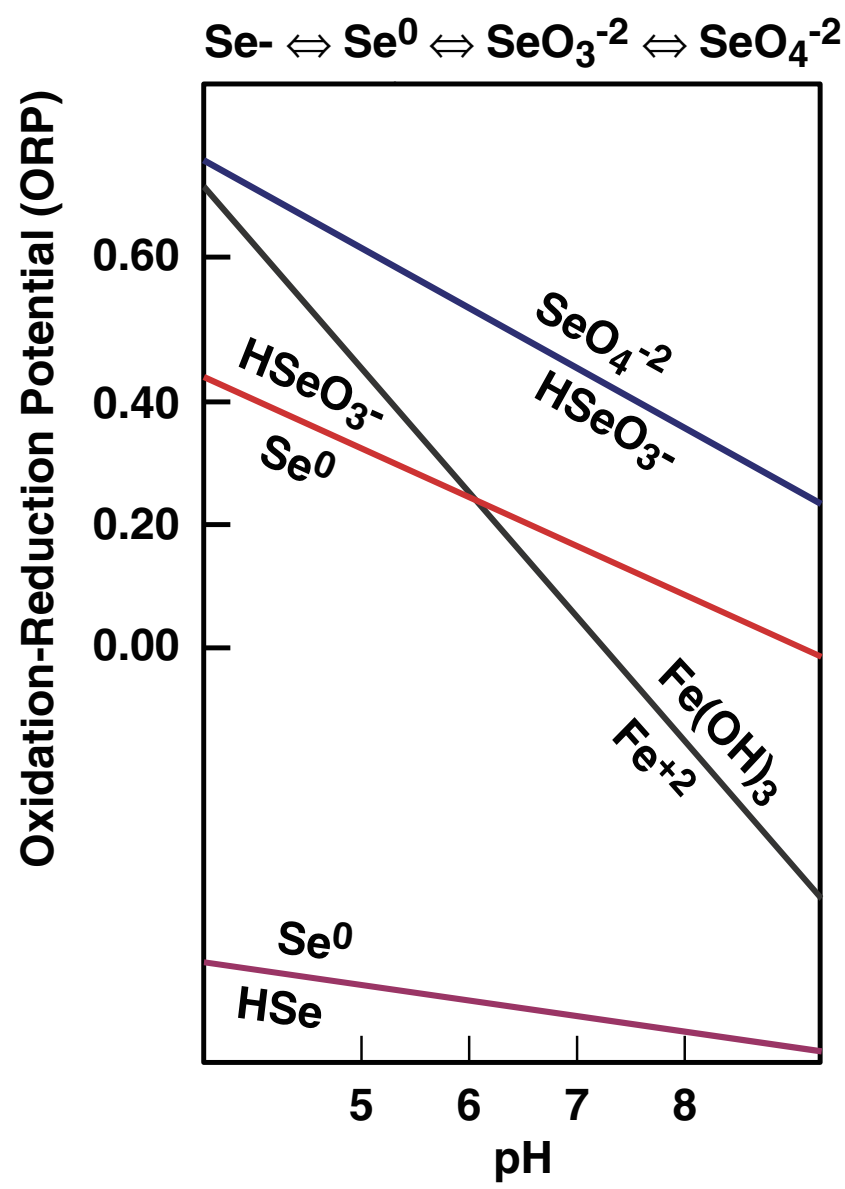

Fig. 2 The equilibrium forms of selenium to be expected in soil at various conditions of $\mathrm{pH}$ and redox potential. Selenide ( $\mathrm{HSe}^{-}$) and elemental $\mathrm{Se}\left(\mathrm{Se}^{0}\right)$ are bio-unavailable, while selenite $\left(\mathrm{HSeO}_{3}{ }^{-}\right)$and selenate $\left(\mathrm{SeO}_{4}{ }^{2-}\right)$ are bioavailable. Adapted from Geering et al. (1968) 
concentrations occurred in flooded Argentina Pampas regions even though they had high soil Se.

The incorporation of selenite and selenate into plant tissues is inadvertent and occurs due to plant metabolic mechanisms designed to accumulate sulfur (Bell et al. 1992; White et al. 2004, 2007; Sors et al. 2005). The application of sulfur fertilizer actually decreases the uptake of Se by dilution (Allaway 1970; Hopper and Parker 1999) because sulfate $\left(\mathrm{SO}_{4}{ }^{2-}\right)$ competes with selenate $\left(\mathrm{SeO}_{4}{ }^{2-}\right)$ uptake by plants (Dhillon and Dhillon 2000; White et al. 2004; Sors et al. 2005; Mackowiak and Amacher 2008). Sulfur fertilization of soils has even led to the occurrence of Se deficiency disease in livestock (Schubert et al. 1961; Allaway 1970).

Selenate remains in the inorganic form in roots, shoots, and leaves, while selenite is the species readily transformed into the amino acids selenocysteine and selenomethionine (Brown and Shrift 1981). A fraction of organoselenium compounds is also volatilized from plant roots (Zieve and Peterson 1984; Zayed et al. 1998). This is lost from the soil. The form of Se, rather than the total concentration in soil, determines the amount of uptake by plants and, thus, the availability to foraging wildlife.

\section{A selenium cycle in nature}

Following the discovery of microbial Se respiration and its importance as a trace nutrient in animals, the existence of a natural biological Se cycle was proposed by Shrift (1964). A modern view of the Se cycle includes inorganic processes and may be termed the biogeochemical Se cycle (Mosher and Duce 1987). In this cycle, shown in Fig. 3, the weathering of rock produces the soluble forms of Se that are incorporated into higher plants as selenate and amino acids. Biologically produced volatile forms such as dimethylselenide are lost as gas (Fleming and Alexander 1972; Barkes and Fleming 1974; Chao et al. 1976; Doran and Alexander 1976; Reamer and Zoller 1980; Zieve and Peterson 1984; Karlson and Frankenberger 1989; Zayed et al. 1998; de Souza et al. 1999; Zhang and Frankenberger 2000). In fact, the abundance of Se in coastal locations is due to the marine biological production of gaseous Se followed by atmospheric deposition (Duce et al. 1975; Lag and Steinnes 1978; Steinnes et al. 1992; Fernandez-Martýnez and Charlet 2009). Mosher and Duce (1987) estimated values from major anthropogenic and natural sources including volcanoes, crustal weathering, and sea spray, reporting a total atmospheric Se flux of $(13-19) \times 10^{9} \mathrm{~g} / \mathrm{year}$, with $60 \%$ of this thought to be of natural origin. This gaseous $\mathrm{Se}$ is eventually oxidized and adsorbed to aerosols, and the resulting particulate forms later deposited on the Earth's surface (Atkinson et al. 1990). Atmospheric deposition may then be

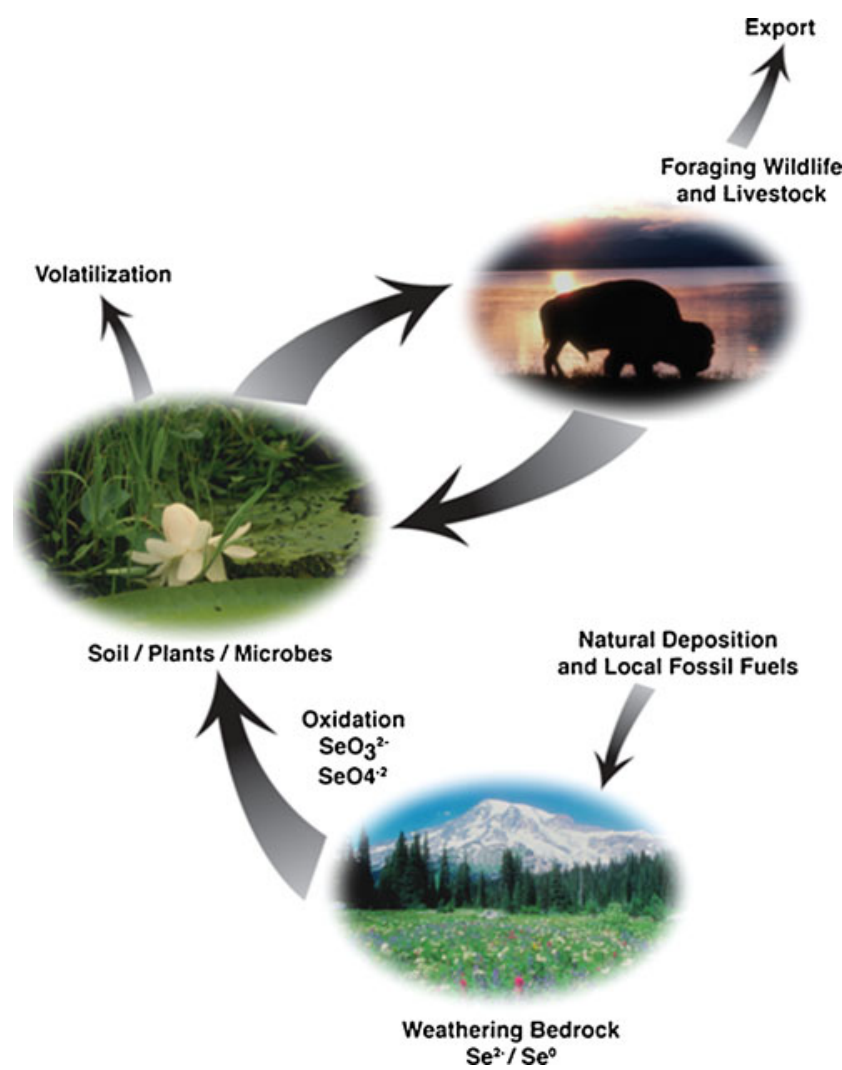

Fig. 3 Simplified view of the natural cycling of Se in the environment. The weathering of rock produces forms of the element that are taken up by plants and/or volatilized. Foraging wildlife consume Se in plants. The amount available for uptake depends on many environmental factors, discussed in the text

the most important source of Se in deficient areas (Haygarth et al. 1991, 1993a).

Loss of Se may result from plant cropping by foraging wildlife, accompanied by non-random spatial mortality patterns. For alpine species such as bighorn sheep, lambing usually occurs at high elevation with the young animals being in the nutrient accumulation stage of growth. Migration to low-elevation range later in the year with subsequent winter-related mortality results in the export of $\mathrm{Se}$ and other minerals from the summer range. Haygarth et al. (1991) calculated that high stocking rates of domestic lambs followed by removal from pasture represented significant losses of Se. Flueck (2009) provided an analogous example of local depletion in the element phosphorous on summer range due to high winter range mortality rates. Finally, the forms of Se excreted by animals are generally unavailable for plant uptake (Butler and Peterson 1963; Peterson and Spedding 1963; Doran and Alexander 1976; Olson et al. 1976; Joblin and Pritchard 1983). Thus, while plants convert the element to more available forms, animals convert Se mainly to unavailable forms and/or export it from key habitats. Furthermore, at higher elevations, selenite and selenate 
may be lost through leaching by rainfall with subsequent transport to lower elevation. There, it often becomes concentrated in flats and flood plains (Webb and Atkinson 1965; Carter et al. 1970; Sivertsen 2004; Steinhöfel et al. 2004). An extreme example of the concentration of Se by leaching is provided by the waterfowl poisoning experienced at Kesterson Reservoir, in California, USA (Presser and Ohlendorf 1987), related to farm runoff.

\section{Anthropogenic effects on the selenium cycle}

The combustion of fossil fuels is a source of atmospheric Se of the same order of magnitude as biogenic sources (Andren et al. 1975; Mosher and Duce 1987). Archived soil and vegetation from southeast England shows increasing Se concentrations in the first half of the twentieth century, followed by declining concentrations since the passage of the clean air legislation (Haygarth et al. 1993b). Thus, industrialization seems to have increased, at least temporarily, atmospheric Se deposition in some areas. However, for remote areas, which often contain the last remaining wildlife habitat, the situation is different. Measurements of the sulfur and Se contents of both Greenland and Antarctic ice have shown that their sulfur content has increased since industrialization, while Se has not (Weiss et al. 1971). Similarly, the influence of continental sources on sulfur concentrations in the northern Pacific is greater than for Se (Mosher et al. 1987). Unlike biogenic Se, anthropogenic Se is not transported to remote locations because combustion-produced $\mathrm{SeO}_{2}$ is readily reduced to unavailable elemental $\mathrm{Se}$ and deposited locally. Therefore, while total Se emissions to the environment have increased, the net result is a Se dilution effect due to competition for plant uptake by increased levels of sulfur.

To this may be added the very effective sequestration of Se by heavy metals such as cadmium, mercury, or lead (Allaway et al. 1967; Combs and Combs 1986; Frost 1987). These metals are also released continuously to the environment by fossil fuel combustion. Acid precipitation was suggested to liberate heavy metals including mercury and cadmium in Sweden, thus reducing Se bioavailability to wildlife (Borg 1987). Wild bison in Canada were also found to have deficient Se levels accompanied by elevated cadmium and mercury as compared to farmed bison (Macneil et al. 1990). Continuing declines of bighorn sheep in the Rocky Mountains have also been suggested to partially stem from anthropogenic biochemical changes in high-elevation mountains resulting in Se deficiency (Williams et al. 2002; Hnilicka et al. 2004).

Thus, the bioavailable Se concentration across the globe may actually be decreasing (Frost 1987; Ermakova and Jovanovic 2010). Fossil fuel combustion is also acidifying the general environment through the precipitation of acidic sulfate and nitrate on the landscape. Acidity favors the reduction of Se to the reduced, biologically unavailable forms, and many authors have reported decreased Se concentrations in plants grown on acid-amended soils (Geering et al. 1968; Goldberg and Glaubig 1988; Ambe et al. 1992; Tachi et al. 1998; Wang et al. 2000). The soil acidification process may be somewhat mitigated by natural soil buffering capacity (James and Riha 1986; Clayton et al. 1991). However, the fact that these capacities can be eventually exceeded was revealed by Blake et al. (1999), who reported that soil $\mathrm{pH}$ at the Rothamsted Experimental Station, UK, dropped from 6.2 to 3.8 in a woodland plot and from 5.2 to 4.2 on a grassland plot between 1883 and 1999. As noted above, soil acidification also increases the solubility of the heavy metals that tie up Se as insoluble selenides. These possible implications of emissions causing acidification, a declining Se cycle, and increased exposure to heavy metals for wild ruminants were described by Flueck (1990) and Flueck and Smith-Flueck (1990).

Lastly, increasing rates of anthropogenic biomass export due to agricultural production are also disturbing the natural Se cycle. In the natural cycle, the majority of the available Se resides in biomass (Gissel-Nielsen and Hamdy 1977; Swaine 1978; Frost 1987) in plants and litter fall (Tiedemann et al. 2000; Jobbagy and Jackson 2004). Selenium accumulates in the upper soil layers and mainly in organic material. However, biomass harvesting and export can remove Se and other nutrients in a short time, also leading to soil acidification which renders Se less bioavailable (Gissel-Nielsen and Bisbjerg 1970; Heylar et al. 1990; Gustafsson et al. 1993; Flueck 1994; Jobbagy and Jackson 2004). Extensive livestock production currently occurs over 45 million square kilometers of rangeland globally. This $\mathrm{Se}$ export also includes the increased biomass burning during the last several centuries (Niklasson and Granstrom 2000).

\section{Implications for management and conservation}

As wildlife habitat is encroached upon for multiple anthropogenic uses, wild animal populations lose access to important natural resources such as low-elevation range and mineral licks. This may result in loss of access to important trace minerals, including Se. If a population is suffering from severe Se deficiency, WMD would occur in deficient young at 3-6 weeks, resulting in muscle stiffness and respiratory distress. Affected muscle has visible striations upon necropsy. The malady may result in sudden death, which obviously reduces the recruitment rates or spontaneous population recovery. In adults, general unthriftiness, late weaning, and periodontal disease are common expressions. Symptoms of the deficiency may also manifest as high rates of capture myopathy or only appear after other stressful 
situations, such as a severe winter. However, chronic, subclinical deficiency may depress population performance and be unrecognized by the wildlife manager. The following paragraphs are a guide to help managers understand under what conditions Se deficiency in wild ungulate populations is possible or even likely.

Rock of volcanic origin is typically low in Se (Carter et al. 1970; Fernandez-Martýnez and Charlet 2009) because the element is volatile at high temperatures. Soils derived from granite or basalt can be expected to be well below the world average of $\sim 400 \mathrm{ppb}$ total Se (Kabata-Pendias and Pendias 1984), and plants growing over granitic bedrock will likely contain low concentrations. In contrast, plants in areas with sedimentary bedrock will contain higher amounts of Se (Dhillon and Dhillon 2000; Mincher et al. 2007). Sites at high elevation also experience losses due to leaching. For these reasons, upland range soils are often deficient (Carter et al. 1970; Ren et al. 1987; Iyengar and Gopal-Ayengar 1988; Haygarth et al. 1991; Wang and Gao 2001). If deficiency is suspected, analysis of soil may be warranted; however, as mentioned above, forage Se concentrations are related to the soil species of Se rather than its total concentration. Analyses that identify Se species rather than total Se rely on specialized and expensive techniques that are not often readily available (Pickering et al. 1995). Fortunately, it is possible to infer the likely species based on easily measured soil parameters such as redox potential $\left(E_{\mathrm{h}}\right.$, a measure of the oxidizing power of the soil) and $\mathrm{pH}$ (Geering et al. 1968). Both are measured with inexpensive probes amenable to field conditions. The combination of these parameters may be used to determine which Se species are most probable at a given site. Thus, risk factors for Se deficiency include high-elevation sites, granitic or basaltic geology, acidic soils, and high precipitation and/or stagnant, waterlogged soils, especially at inland locations.

Should the measured soil $E_{\mathrm{h}}$ and $\mathrm{pH}$ suggest that soil Se is in an unavailable form, it may be desirable to sample vegetation. The total concentration of Se in plants is readily measured by many laboratories, although some provide inadequate minimum detection limits. Plant species that are actually used as forage should be sampled, and the same species should be used in repetitive sampling campaigns. Different species may accumulate Se at different rates. Some plants bioaccumulate Se to high concentrations, but are seldom used as forage. The best-known example is Astragalus bisulcatus which may contain Se in leaves and seeds at thousands of milligrams per kilogram (Rosenfeld and Beath 1964; Ulrich and Shrift 1968; Sors et al. 2005). Selenium accumulators have a characteristic odor produced by dimethyldiselenide. Foraging wildlife and/or livestock may actually be poisoned by eating these species.

For livestock, forage values of $<0.1 \mathrm{ppm}$ on a dry weight basis are considered deficient (Allaway and
Hodgson 1964). It is commonly assumed that wildlife requirements would be lower, although minimum requirements are unknown and may vary between species. The literature reviewed here suggests that forage species concentrations $<0.05 \mathrm{ppm}$ may indicate a risk factor. As we have already shown, a wide range of Se values may exist in individual animals, probably at least in part indicating that they feed on various species of plants or at various locations.

If some risk factors above are indicated, then sampling of the animal population itself may be warranted. Selenium in liver is the commonly evaluated metric, and as already discussed, blood and hair Se levels have sometimes been shown to be correlated with liver Se. Muscle tissue has also been used. In either case, individual animals need to be sacrificed, and this may not be practical for unhunted or endangered populations. A tissue sample of adequate size should be determined after consultation with the selected laboratory to ensure that enough material is collected to give adequate detection limits and should be kept cool, preferably frozen, and protected from cross-contamination. The sampling of hair could be conducted without the need to sacrifice animals; however, to our knowledge, a rigorous study showing the relationship between hair and liver Se has not yet been done.

Furthermore, it is difficult to determine what levels constitute deficiency. Based on the literature reviewed here, we have provided recommendations in Table 1. Should the conclusion be made that a population is performing poorly due to Se deficiency, the wildlife manager has little choice but to provide supplementation where that is possible. Mineral salt blocks with Se supplements have long been used in domestic stock nutrition and have been used to improve recruitment in wild populations. Care in the placement of blocks should be used to mitigate the possibility that unnatural congregations of supplemented animals might occur, which could introduce other management problems such as predation or disease. If deficiency was produced by loss of access to specific habitat components, it may be preferable to restore that access rather than to provide supplements. Unfortunately, habitat restoration is not always a practical alternative.

Packard's (1946) classical study on bighorn sheep elucidated the reasons for poor population performance by considering pre-Columbian distribution and migratory behavior, market hunting by settlers, extirpations of populations at low elevations, arrival of livestock, and characteristics of the high-elevation habitat where sheep still remained. He found that sheep previously used winter ranges with sedimentary bedrock and mineral licks, whereas current herds were forced to remain at high elevations. Anthropogenically caused range contraction of ungulates are heavily skewed toward loss of low-elevation ranges (Channell and Lomolino 2000; Laliberte and Ripple 2004). 
Thus, loss of traditional seasonal movements has resulted in many sedentary wildlife populations and associated seasonal deficiencies in forage quality. This has been considered an important cause of declining herds and one of the largest problems challenging long-term persistence (Risenhoover et al. 1988). In situations where residual wild populations fail to respond to management or protection, the possibility that subclinical deficiency of Se or other trace elements is a factor should be considered.

\section{Conclusions}

The decline of wild ungulate populations is a worldwide recurrent problem, and the multifactorial nature of ecology, combined with the difficulties of studying elusive wild animals, tends to reveal only proximate factors like clinical disease or predation events. Underlying causes of population declines that may be more important, such as mineral and forage nutrition, are sometimes overlooked. Micronutrient deficiencies, including for Se, are especially challenging to understand because they result in a large gradient of possible effects without providing a clear and specific signature when subclinical. However, during this phase, much damage may be occurring because a slow decline in remnant populations may result in local extinctions which are difficult to document or counter. In such cases, expensive investments in habitat, restriction of hunting regulations, or predator control will probably fail to recover the affected population. The literature reviewed here suggests that subclinical nutritional Se deficiency may be common, especially at alpine locations.

From a mineral nutritional view, the most productive sites for wild ruminant herbivores are valley floors, riparian areas, flood plains, and sedimentary beds containing deeper soils and natural mineral licks. As has been shown, Se is leached to lower elevations by natural processes and has inherently higher concentrations in sedimentary soils. In addition, milder climate and other factors result in food intake of higher mineral density and low oxidative stress on animals. When access to such nutrient hot spots is no longer possible, or vertically transmitted migration behavior to get there has been eliminated through anthropogenic forces, the remaining animals are forced to live in a nutritionally marginal habitat. When a population in such circumstances fails to respond to management designed to increase its numbers, mineral nutrition deficiencies particularly of Se should be considered by the wildlife manager.

Acknowledgments We greatly appreciate the many constructive comments from three anonymous reviewers.

\section{References}

Aastrup P, Riget F, Dietz R, Asmund G (2000) Lead, zinc, cadmium, mercury, selenium and copper in Greenland caribou and reindeer (Rangifer tarandus). Sci Total Environ 245:149-159

Alexander TL (1986) Management and diseases of deer. Veterinary Deer Society, London

Allaway WH (1970) Sulphur-selenium relationships in soils and plants. Sulphur Inst J 6:3-5

Allaway WH, Cary EE, Ehlig CF (1967) The cycling of low levels of selenium in soils, plants and animals. In: Muth OH, Oldfield JE, Weswig PH (eds) Selenium in biomedicine. AVI Publishing, Westport, pp. 273-296

Allaway WH, Hodgson JF (1964) Symposium on nutrition, forage and pastures: selenium in forages as related to the geographic distribution of muscular dystrophy in livestock. J Anim Sci 23:271-277

Allen ME, Ullrey DE (2004) Relationships among nutrition and reproduction and relevance for wild animals. Zoo Biol 23:475-487

Ambe S, Chen SY, Ohkubo Y, Kobayashi Y, Iwamoto M, Ambe F (1992) Application of the radioactive multitracer technique to a study of adsorption of metal ions on $\gamma-\mathrm{Fe}_{2} \mathrm{O}_{3}$. Chem Lett 21:1059-1062

Andren AW, Klein DH, Talmi Y (1975) Selenium in coal-fired steam plant emissions. Environ Sci Technol 9:856-858

Andrews ED, Hartley WJ, Grant AB (1968) Selenium-responsive diseases of animals in New Zealand. NZ Vet J 16:3-17

Arthur JR (2000) The glutathione peroxidases. Cell Mol Life Sci $57: 1825-1835$

Arthur JR, Beckett GJ, Mitchell JH (1999) The interactions between selenium and iodine deficiencies in man and animals. Nutr Res Rev 12:55-73

Atkinson R, Aschmann SM, Hasegawa D, Thompson-Eagle ET, Frankenberger WT Jr (1990) Kinetics of the atmospherically important reactions of dimethyl selenide. Environ Sci Technol 24:1326-1332

Backhaus B, Backhaus R (1983) The cadmium-content of roe deer in the Egge mountains. Zeits Jagdwiss 29:213-218

Bakonyi T, Radak Z (2004) High altitude and free radicals. J Sports Sci Med 3:64-69

Barkes L, Fleming RW (1974) Production of dimethylselenide gas from inorganic selenium by eleven soil fungi. Bull Environ Contam Tox 12:308-311

Barry TN (1983) Iodine. In: Grace ND (ed) The mineral requirements of grazing ruminants. Occasional Publication No. 9. New Zealand Society of Animal Production, Hamilton

Beckett GJ, Arthur JR (2005) Selenium and endocrine systems. J Endocrinol 184:455-465

Bell PF, Parker DR, Page AL (1992) Contrasting selenate sulfate interaction in selenium accumulating and nonaccumulating plant species. Soil Sci Soc Am J 56:1818-1824

Berger K, Mohry H, Schuster H (1989) Geoökologische Stoffflüsse und Konsequenzen anthropogener Aktivitäten in der Landschaft. VEB Deutscher Verlag f Grundstoffindustrie, Leipzig

Besselmann D, Schaub D, Wenker C, Völlm J, Robert N, Schelling C, Steinmetz H, Clauss M (2008) Juvenile mortality in captive lesser kudu (Tragelaphus imberbis) at Basle Zoo and its relation to nutrition and husbandry. J Zoo Wildl Med 39:86-91

Beytut E, Karatas F, Beytut E (2002) Lambs with white muscle disease and selenium content of soil and meadow hay in the region of Kars, Turkey. Vet J 163:214-217

Blake L, Goulding WT, Mott CJB, Johnston AE (1999) Changes in soil chemistry accompanying acidification over more than 100 years under woodland and grass at Rothamsted Experimental Station, UK. Euro J Soil Sci 50:401-412

Bodie WL, O'Gara BW (1980) A description of "weak fawn syndrome" in pronghorn antelope. Proc Bien Pronghorn Antelope Workshop 9:59-70 
Bogden JD, Kemp FW, Chen X, Stagnaro-Green A, Stein TP, Scholl TO (2006) Low-normal serum selenium early in human pregnancy predicts lower birth weight. Nutr Res 26:497-502

Borg K (1987) A review of wildlife diseases from Scandinavia. J Wildl Dis 23:527-533

Brady PS, Brady LJ, Whetter PA, Ullrey DE, Fay LD (1978) The effect of dietary selenium and vitamin $\mathrm{E}$ on biochemical parameters and survival of young among white-tailed deer (Odocoileus virginianus). J Nutr 108:1439-1448

Brown TA, Shrift A (1981) Exclusion of selenium from proteins of selenium-tolerant Astragalus species. Plant Physiol 67:10511053

Butler GW, Peterson PJ (1963) Availability of selenium in forage to ruminants. NZ Soc Anim Prod 23:13-27

Carter DL, Robbins CW, Brown MJ (1970) Selenium concentrations in forage on some high Northwestern ranges. J Range Manage 23:234-238

Channell R, Lomolino MV (2000) Dynamics biogeography and conservation of endangered species. Nature 403:84-86

Chao YK, Wong PTS, Silverberg BA, Luxon PL, Bengert GA (1976) Methylation of selenium in the aquatic environment. Science 192:1130-1131

Choudhury N, Gorman KS (2003) Subclinical prenatal iodine deficiency negatively affects infant development in northern China. J Nutr 133:3162-3165

Clayton JL, Kennedy DA, Nagel T (1991) Soil response to acid deposition, Wind River Mountains, Wyoming: I. Soil properties. Soil Sci Soc Am J 55:1427-1439

Coggins VL (2006) Selenium supplementation, parasite treatment, and management of bighorn sheep at Lostine River, Oregon. Bienn Symp North Wild Sheep Goat Counc 15:98-106

Combs GF Jr, Combs SB (1986) The role of selenium in nutrition. Academic, New York

Combs CF Jr, Scott ML (1977) Nutritional interrelationships of vitamin $\mathrm{E}$ and selenium. Bioscience 27:467-473

Cox MK (2006) Effects of mineral supplements on California bighorn sheep in northern Nevada. Bienn Symp North Wild Sheep and Goat Council 15:107-120

Custer TW, Cox E, Gray B (2004) Trace elements on moose (Alces alces) found dead in Northwestern Minnesota, USA. Sci Total Environ 330:81-87

Dalir-Naghadeh B, Rezaei SA (2008) Assessmant of serum thyroid hormone concentrations in lambs with selenium deficiency myopathy. Am J Vet Res 69:659-663

Dean R, Hnilicka P, Kreeger T, Delcurto T (2004) An investigation into the selenium requirement for Rocky Mountain bighorn sheep. Bienn Symp North Wild Sheep and Goat Council 13:95-99

de Souza MP, Chu D, Zhao M, Zayed AM, Ruzin SE, Schichnes D, Terry N (1999) Rhizosphere bacteria enhance selenium accumulation and volatilization by Indian mustard. Plant Physiol 119:565-573

Dhillon KS, Dhillon SK (2000) Selenium accumulation by sequentially grown wheat and rice as influenced by gypsum application in a seleniferous soil. Plant Soil 227:243-248

Dierenfeld ES, Jessup DA (1990) Variation in serum alphatocopherol, retinol, cholesterol, and selenium of free-ranging mule deer (Odocoileus hemionus). J Zoo Wildl Med 21:425432

Doran JW, Alexander M (1976) Microbial formation of volatile selenium compounds in soil. Soil Sci Soc Am J 40:687-690

Downey CM, Horton CR, Carlson BA, Parsons TE, Hatfield DL, Hallgrimsson B, Jirik FR (2009) Osteo-chondroprogenitorspecific deletion of selenocysteine tRNA gene, Trsp, leads to chondronecrosis and abnormal skeletal development: a putative model for Kashin-Beck disease. PLoS Genet 5(8):e1000616. doi:10.137 1/journal.pgen.1000616
Duce RA, Hoffman GL, Zoller WH (1975) Atmospheric trace metals at remote northern and southern hemisphere sites: pollution or natural? Science 187:59-61

Dunbar MR, Velarde R, Gregg MA, Bray M (1999) Health evaluation of a pronghorn antelope population in Oregon. J Wildl Dis $35: 496-510$

Duntas LH (2010) Selenium and the thyroid: a close-knit connection. J Clin Endocrinol Metab 95:5180-5188

Ebert R, Seefried L, Jakob F (2008) Trace elements and bone health Osteologie 17:60-66

Ebert R, Jakob F (2007) Selenium deficiency as a putative risk factor for osteoporosis. Int Congr Series 1297:158-164

Elrashidi MA, Adriano DC, Workman SM, Lindsay WL (1987) Chemical equilibria of selenium in soils: a theoretical development. Soil Sci 144:141-152

Emakova V, Jovanovic L (2010) Selenium deficiency as a consequence of human activity and its correction. J Geochem Expl 107:193-199

Fernandez-Martýnez A, Charlet L (2009) Selenium environmental cycling and bioavailability: a structural chemists point of view. Rev Environ Sci Biotechnol 8:81-110

Fielder PC (1986) Implications of selenium levels in Washington mountain goats, mule deer, and Rocky Mountain elk. Northwest Sci 60:15-20

Fleming RE, Alexander M (1972) Dimethyselenide and demethyltelluride formation by a strain of Penicillium. Appl Microbiol 24:424-429

Flueck WT (1990) Possible impact of emmissions on trace mineral availability to free-ranging ruminants: selenium as an example. Zeits Jagdwiss 36:179-185

Flueck WT (1991) Whole blood selenium levels and glutathione peroxidase activity in erythrocytes of black-tailed deer. J Wildl Manage 55:26-31

Flueck WT (1994) Effect of trace elements on population dynamics: selenium deficiency in free-ranging black-tailed deer. Ecology $75: 807-812$

Flueck WT (2009) Biotic translocation of phosphorous: the role of deer in protected areas. Sustainability 1:104-119

Flueck WT, Smith-Flueck JM (1990) Selenium deficiency in deer. The effect of a declining selenium cycle? Trans Congr Int Union Game Biol 19:292-301

Flueck WT, Smith-Flueck JM (2008) Age-independent osteopathology in skeletons of a South American cervid, the Patagonian huemul (Hippocamelus bisulcus). J Wildl Dis 44:636-648

Flueck WT, Smith-Flueck JM (2011a) Recent advances in the nutritional ecology of the Patagonian huemul: implications for recovery. Anim Prod Sci 51:311-326

Flueck WT, Smith-Flueck JM (2011b) Intraspecific phenotypic variation in deer: the role of genetic and epigenetic processes. Anim Prod Sci 51:365-374

Flueck WT, Norman BB, Smith-Flueck JM, Jacobsen NK (1989) The potential of increasing deer production by broad scale selenium supplementation in Northern California. Int Symp Industr Selenium Tellurium 4:713-717

Frost DV (1987) Why the level of selenium in the food chain appears to be decreasing. In: Combs GF, Spallholz JE, Levander OA, Oldfield JE (eds) Selenium in biology and medicine. Part A. AVI Publishing, New York

Frøslie A, Norheim G, Rambaek JB, Steinnes E (1984) Levels of trace elements in liver from Norwegian moose, reindeer and red deer in relation to atmospheric deposition. Acta Vet Scand 25:333-345

Galgan V, Frank A (1995) Survey of bioavailable selenium in Sweden with the moose (Alces alces) as monitoring animal. Sci Total Environ 172:37-45

Geering HR, Cary EE, Jones LHP, Allaway WH (1968) Solubility and redox criteria for the possible forms of selenium in soils. Soil Sci Soc Amer Proc 32:35-40 
Gil S, Hevia S, Dallorso M, Resnizky S (2004) Selenium in bovine plasma, soil and forage measured by neutron activation analysis. Arg Bras Med Vet Zootec 56:264-266

Gissel-Nielsen G, Hamdy AA (1977) Leaching of added selenium in soils low in native selenium. Z Pflanzenern Bodenk 140:193-198

Gissel-Nielsen G, Bisbjerg B (1970) The uptake of applied selenium by agricultural plants. 2. The utilization of various selenium compounds. Plant Soil 32:382-396

Goldberg S, Glaubig RA (1988) Anion sorption on a calcareous, montmorillonitic soil-selenium. Soil Sci Soc Am J 52:954-958

Grace ND, Wilson PR (2002) Trace element metabolism, dietarty requirements diagnosis and prevention of deficiencies in deer. NZ Vet J 50:252-259

Griner LA (1978) Muscular dystrophy in ungulates at the San Diego Zoo and San Diego Wild Animal Park. Verhand XX Internationalen Symposiums uber die Erkrankungen der Zootiere

Gustafsson JP, Jacks G, Stegmann B, Ross HB (1993) Soil acidity and adsorbed anions in Swedish forest soils-long-term changes. Agr Ecosyst Environ 47:103-115

Hadlow WJ (1955) Degenerative myopathy in a white-tailed deer, Odocoileus virginianus. Cornell Vet 45:538-547

Harthill M (2011) Review: micronutrient selenium deficiency influences evolution of some viral infectious diseases. Biol Trace Elem Res 30:77-83

Hatfield DL, Gladyshev VN (2002) How selenium has altered our understanding of the genetic code. Mol Cell Biol 22:35653576

Haygarth PM, Harrison AF, Jones KC (1993a) Geographical and seasonal variation in deposition of seleneium to vegetation. Environ Sci Technol 27:2878-2884

Haygarth PM, Cooke AI, Jones KC, Harrison AF, Johnston A (1993b) Long-term change in the biogeochemical cycling of atmospheric selenium: deposition to plants and soil. J Geophys Res 98:1676916776

Haygarth PM, Jones KC, Harrison AF (1991) Selenium cycling through agricultural grasslands in the UK: budgeting the role of the atmosphere. Sci Total Environ 103:89-111

Hebert D, Cowan IM (1971a) Natural salt licks as a part of the ecology of the mountain goat. Can J Zool 49:605-610

Hebert D, Cowan IM (1971b) White muscle disease in the mountain goat. J Wildl Manage 35:752-756

Hein RG, Talcott PA, Smith JL, Meyers WL (1994) Blood selenium values of selected wildlife populations in Washington. Northwest Sci 68:185-188

Helyar KR, Cregan PD, Godyn DL (1990) Soil acidity in New South Wales - current $\mathrm{pH}$ values and estimates of acidification rates. Aust J Soil Res 28:523-537

Hidiroglou M, Proulx J, Jolette J (1987) Effect of intraruminally administered, selenium soluble-glass boluses on selenium status in cows and their calves. J Anim Sci 65:815-820

Hnilicka PA, Mionczynski J, Mincher BJ, States J, Hinschberger M, Oberlie S, Thompson C, Yates B, Siemer DD (2004) Bighorn sheep lamb survival, trace minerals, rainfall, and air pollution: are there any connections? Bienn Symp North Wild Sheep Goat Council 13:69-94

Hopper JL, Parker DR (1999) Plant availability of selenite and selenate as influenced by the competing ions phosphate and sulfate. Plant Soil 210:199-207

Humann-Ziehank E, Ganter M, Hennig-Pauka I, Binder A (2008) Trace mineral status and liver and blood parameters in sheep without mineral supply compared to local roe deer (Capreolus capreolus) populations. Small Rum Res 75:185-191

Iyengar GV, Gopal-Ayengar AR (1988) Human health and traceelements including effects on high-altitude populations. Ambio $17: 31-35$
Jackson TA (1997) Long-range atmospheric transport of mercury to ecosystems, and the importance of anthropogenic emissionscritical review and evaluation of the published evidence. Environ Rev 5:99-120

James BR, Riha SJ (1986) $\mathrm{pH}$ buffering in forest soil organic horizons: relevance to acid precipitation. J Environ Qual $15: 229-234$

Jarzyńska G, Falandysz J (2011) Selenium and 17 other largely essential and toxic metals in muscle and organ meast of red deer (Cervus elaphus) - consequences to human health. Environ Int $37: 882-888$

Jobbagy EG, Jackson RB (2004) The uplift of soil nutrients by plants: biogeochemical consequences across scales. Ecology 85:2380-2389

Joblin KN, Pritchard MW (1983) Urinary effect on variations in the selenium and sulphur contents of ryegrass from pasture. J Plant and Soil 70:69-76

Johnson WH, Norman BB, Dunbar JR (1979) Selenium improves weight gain of beef calves. Calif Agr 33:14-16

Jones MB, Rendig VV, Norman BB, Center DM, Dally MR, Williams WA (1987) Selenium enhances lamb gains on sulfur-fertilized pastures. Calif Agri 41:14-16

Kabata-Pendias A, Pendias K (1984) Trace elements in soils and plants. CRC, Boca Raton

Kalkus JW (1920) A study of goitre and associated conditions in domestic animals. Wash Agr Expt Sta Bull 156:1-48

Karlson U, Frankenberger WT Jr (1989) Accelerated rates of selenium volitalization from California soils. Soil Sci Soc Am J 53:749753

Kasaikina MV, Kravtsova MA, Lee BC et al (2011) Dietary selenium affects host selenoproteome expression by influencing the gut microbiota. FASEB J 25:2492-2499

Kaushal N, Hegde S, Lumadue J, Paulson RF, Prabhu KS (2011) The regulation of erythropoiesis by selenium in mice. Antioxid Redox Signal 14:1403-1412

Kipp AP, Banning A, van Schothorst EM et al (2012) Marginal selenium deficiency down-regulates inflammation-related genes in splenic leukocytes of the mouse. J Nutr Biochem. doi:10.1016/ j.jnutbio.2011.06.011

Knox DP, Reid HW, Peters JG (1987) An outbreak of selenium responsive unthriftiness in farmed red deer (Cervus elaphus). Vet Rec 120:91-92

Köhrle J (2005) Selenium and the control of thyroid hormone metabolism. Thyroid 15:841-853

Köhrle J, Jakob F, Contempre B, Dumont JE (2005) Selenium, the thyroid, and the endocrine system. Endocr Rev 26:944-984

Köhrle J (2000) The selenoenzyme family of deiodinase isozymes controls local thyroid hormone availability. Rev Endocr Metabol Disord 1:49-58

Kotyzová D, Cerná P, Lešetický L, Eybl V (2010) Trace elements status in selenium-deficient rats - interaction with cadmium. Biol Trace Elem Res 136:287-293

Kozat $S$ (2007) Serum $T_{3}$ and $T_{4}$ concentrations in lambs with nutritional myodegeneration. J Vet Intern Med 21:1135-1137

Kryukov GV, Novoselov SV, Lobanov AV, Zehtab O, Guigo R, Castellano S, Gladyshev VN (2003) Characterization of mammalian selenoproteomes. Science 300:1439-1443

Kubota J, Cary EE (1982) Cobalt, molybdenum, and selenium. In: Methods of soil analysis, part 2: chemical and microbiological properties-Agronomy Monograph no. 9 (2nd edn). Soil Science Society of America, Madison

Kumar N, Garg AK, Dass RS, Chaturvedi VK, Mudgal V, Varshney VP (2009) Selenium supplementation influences growth performance, antioxidant status and immune response in lambs. Anim Feed Sci Technol 153:77-87

Lag J, Steinnes E (1978) Regional distribution of selenium and arsenic in humus layers of Norwegian forest soils. Geoderma 20:3-14 
Lakin HW (1972) Selenium accumulation in soils and its absorption by plants and animals. Geol Soc Am Bull 83:181-190

Laliberte AS, Ripple WJ (2004) Range contractions of North American carnivores and ungulates. Bioscience 54:123-138

Lazarus M, Orct T, Blanuŝa M, Vicković I, Ŝsôtarić B (2008) Toxic and essential metal concentrations in four tissues of red deer (Cervus elaphus) from Baranja, Croatia. Food Addit Contam 25:270-283

Levander OA, Ager AL, Beck MA (1995) Vitamin E and selenium: contrasting and interacting nutritional determinants of host resistance to parasites and viral infections. Proc Nutr Soc 54:475-487

Mackintosh CG, Gill J, Turner K (1989) Selenium supplementation of young red deer (Cervus elaphus). NZ Vet J 37:143-145

Mackowiak CL, Amacher MC (2008) Soil sulfur amendments suppress selenium uptake by alfalfa and western wheatgrass. J Environ Qual 37:772-779

Macneil JD, Patterson JR, Salisbury CD, Tessaro SV (1990) An investigation on the trace element status of bison in Wood Buffalo National Park and of ranch-raised bison in Saskatchewan, Canada. Int J Environ Anal Chem 41:99-104

Maiers DT, Wichlacz PL, Thompson DL, Bruhn DF (1988) Selenate reduction by bacteria from a selenium-rich environment. Appl Environ Microbiol 54:2591-2593

Masscheleyn PH, Delaune RD, Patrick WH Jr (1990) Transformation of selenium as affected by sediment oxidation-reduction potential and $\mathrm{pH}$. Environ Sci Technol 24:91-96

Matamoros R, Conteras PA, Wittwer F, Mayagora MI (2003) Hypothyroidism in ruminants. Arch Med Vet 35:1-11

Matzke P (1986) Ueber einige gesundheitliche Probleme in Damwildgehegen zur Fleischerzeugung. Tieraerztl Prax 14:471-475

McCann JC, Ames BN (2011) Adaptive dysfunction of selenoproteins from the perspective of the triage theory: why modest selenium deficiency may increase risk of diseases of aging. FASEB J 25:1793-1814

McDowell LR, Forrester DJ, Linda SB, Wright SD, Wilkinson NS (1995) Selenium status of white-tailed deer in southern Florida. J Wildl Dis 31:205-211

McDowell LR (1989) Vitamins in animal nutrition-comparative aspects to human nutrition. In: McDowell LR (ed) Vitamin E. Academic Press, London, pp. 93-131

Milewski A (2002) Elephant diet at the edge of the Fynbos Biome, South Africa. Pachyderm 32:29-38

Mills A, Milewski A (2007) Geophagy and nutrient supplementation in the Ngorongoro Conservation Area, Tanzania, with particular reference to selenium, cobalt and molybdenum. J Zool 271:110 118

Mincher BJ, Mionczynski J, Hnilicka PA, Ball RD, Houghton TX (2008) Some aspects of geophagia in Wyoming bighorn sheep (Ovis canadensis). Eur J Wildl Res 54:192-198

Mincher BJ, Mionczynski J, Hnilicka PA (2007) Soil redox chemistry limitation of selenium concentration in Carex species sedges. Soil Sci 179:733-739

Moreno-Reyes R, Egrise D, Neve J, Pasteels J-L, Schoutens A (2001) Selenium deficiency-induced growth retardation is associated with an impaired bone metabolism and osteopenia. J Bone Min Res 16:1556-1563

Moreno-Reyes R, Suetens C, Mathieu F, Begaux F, Zhu D, Rivera MT, Boelaert M, Neve J, Perlmutter N, Vanderpas L (1998) KashinBeck osteoarthropathy in rural Tibet in relation to selenium and iodine status. N Engl J Med 339:1112-1120

Morton J, Carolan VA, Gardiner PHE (2002) Removal of exogenously bound elements from human hair by various washing procedures and determination by inductively coupled plasma mass spectrometry. Anal Chem Acta 455:23-34

Mosher BW, Duce RA (1987) A global atmospheric selenium budget. J Geophys Res 92:13289-13298
Mosher BW, Duce RA, Prospero JM, Savoie DL (1987) Atmospheric selenium: geographical distribution and ocean to atmosphere flux in the Pacific. J Geophys Res 92:13277-13287

Mueller M, Banning A, Brigelius-Flohe R, Kipp A (2010) Nrf2 target genes are induced under marginal selenium-deficiency. Genes Nutr 5:297-307

Muth $\mathrm{OH}$ (1955) White muscle disease (myopathy) in lambs and calves. I. Occurrence and nature of the disease under Oregon conditions. J Am Vet Med Assoc 142:355-361

Myneni SCB, Tokunaga TK, Brown GE Jr (1997) Abiotic selenium redox transformations in the presence of $\mathrm{Fe}(\mathrm{II}, \mathrm{III})$ oxides. Science 278:1106-1109

National Research Council (1983) Selenium in nutrition. National Academy Press, Washington, DC

National Zoological Park (1972) 1971 annual report, National Zoological Park. Smithsonian Institution Press, Washington, DC

National Zoological Park (1974) 18-months report, July 1, 1971December 31, 1972, National Zoological Park. Smithsonian Institution Press, Washington, DC

Neville TL, Caton JS, Hammer CJ, Reed JJ, Luther JS, Taylor JB, Redmer DA, Reynolds LP, Vonnahme KA (2010) Ovine offspring growth and diet digestibility are influenced by maternal selenium supplementation and nutritional intake during pregnancy despite a common postnatal diet. J Anim Sci 88:3645-3656

Niklasson M, Granstrom A (2000) Numbers and sizes of fires: longterm spatially explicit fire history in a Swedish boreal landscape. Ecology 81:1484-1499

Oh SH, Sunde RA, Pope AL, Hoekstra WC (1976) Gltathione peroxidase response to selenium intake in lambs fed aTorula yeastbased, artificial milk. J Anim Sci 42:977-983

O'Hara TM, Carroll G, Barboza P, Mueller K, Blake J, Wosher V, Willetto C (2001) Mineral and heavy metal status as related to a mortality event and poor recruitment in a moose population in Alaska. J Wildl Dis 37:509-522

Oliver MN, Ross-McGauran G, Jessup DA, Norman BB, Franti CE (1990) Selenium concentrations in blood of free-ranging mule deer in California. Trans West Sec Wildl Soc 26:80-86

Olson OE, Cary EE, Allaway WH (1976) Absorption of trimethylselenonium by plants. Agron J 68:805-809

Oremland RS, Blum JS, Culbertson CW, Visscher PT, Miller LG, Dowdle P, Strohmaier FE (1994) Isolation, growth, and metabolism of an obligately anaerobic, selenate-respiring bacterium, strain SES-3. Appl Environ Microbiol 60:3011-3019

Oremland RS, Hollibaugh JT, Maest AS, Presser TS, Miller LG, Culbertson CW (1989) Selenate reduction to elemental selenium by anaerobic bacteria in sediments and culture: biogeochemical significance of a novel, sulfate-independent respiration. Appl Environ Microbiol 55:3011-3019

Packard FM (1946) An ecological study of the bighorn sheep in Rocky Mountain National Park, Colorado. J Mammal 27:328

Pavlata L, Prasek J, Filipek J, Pechova A (2004) Influence of parenteral administration of selenium and vitamin $\mathrm{E}$ during pregnancy on selected metabolic parameters and colostrum quality in dairy cows at parturition. Vet Med Czech 49:149-155

Perrault J, Wyneken J, Thompson LJ, Johnson C, Miller DL (2011) Why are hatching and emergence success low? Mercury and selenium concentrations in nesting leatherback sea turtles (Dermochelys coriacea) and their young in Florida. Marine Poll Bull 62:1671-1682

Peterson PJ, Spedding DJ (1963) The excretion by sheep of 75 selenium incorporated into red clover (Trifolium pretense): the chemical nature of the excreted selenium and its uptake by three plant species. NZ J Ag Res 6:13-23

Pfeifer H, Conrad M, Roethlein D, Kyriakopoulos A, Brielmeier M, Bornkamm GW, Behne D (2001) Identification of a specific 
sperm nuclei selenoenzyme necessary for protamine thiol crosslinking during sperm maturation. FASEB J 15:1236-1238

Pickering IJ, Brown GE Jr, Tokunaga TK (1995) Quantitative speciation of selenium in soils using X-ray absorption spectroscopy. Environ Sci Technol 29:2456-2458

Pilarczyk B, Tomza-Marciniak A, Pilarczyk R, Hendzel D, Blaszczyk B, Bąkowska M (2011a) Tissue distribution of selenium and effect of season and age on selenium content in roe deer from northwestern Poland. Biol Trace Elem Res 140:299-307

Pilarczyk B, Drozd R, Pilarczyk R, Tomza-Marciniak A, Jankowiak D, Hendzel D, Kuba J, Kowalska J (2011b) Glutathione peroxidase (GSHPx) activity in the liver of red deer in relation to hepatic selenium concentrations, sex, body weight and season of year. Biol Trace Elem Res 144:560-569

Pilarczyk B, Hendzel D, Pilarczyk R, Tomza-Marciniak A, Blaszczyk B, Dąbrowska-Wieczorek M, Bąkowska M, Adamowicz E, Bujak $\mathrm{T}$ (2010) Liver and kidney concentrations of selenium in wild boars (Sus scofra) from north-western Poland. Eur J Wildl Res 56:797-802

Pilarczyk B, Balicka-Ramisz A, Ramisz A, Adamowicz E, Pilarczyk R, Tomza-Marciniak A, Bąkowska M (2009) Selenium concentration in liver and kidney of free living animals (roe and red deer) from West Pomerania (Poland). Eur J Wildl Res 55:279-283

Pine DS, Mansfield TM (1983) Physical condition and reproductive status of the Santa Lucia deer herd, Monterey County, California. Cal Fish and Game Admin Rep 83-3:1-5

Pollock B (2005) Trace elements status of white-tailed red deer (Odocoileus virginianus) and moose (Alces alces) in Nova Scotia. Wildlife Damage Management, Internet Center for Canadian Cooperative Wildlife Health Centre: Newsletters \& Publications, University of Nebraska-Lincoln, $33 \mathrm{pp}$

Porter WL, Scott RS, Manktelow BW (1970) The occurrence of pariodontal disease in sheep in relation to superphosphate topdressing, stocking rate and other related factors. NZ Vet J 18:2127

Potter BJ, Mano MT, Belling GB, McIntosh GH, Hua C, Cragg BG, Marshall J, Wellby ML, Hetzel BS (1982) Retarded fetal brain development resulting from severe dietary iodine deficiency in sheep. Neuropathol Appl Neurobiol 8:303-313

Presser TS, Ohlendorf HM (1987) Biogeochemical cycling of selenium in the San Joaquin Valley, California, USA. Environ Manage 11:805-821

Puls R (1994) Mineral levels in animal health: diagnostic data, 2nd edn. Sherpa International, Clearbrook, p 356

Raisbeck MF, O'Toole DO, Schamber RA, Belden EL, Robinson LJ (1996) Toxicological evaluation of a high-selenium hay diet in captive pronghorn antelope (Antilocapra americana). J Wildl Dis 32:9-16

Raymond LJ, Ralston NVC (2004) Mercury: selenium interactions and health implications. Seychelles Med Dent J 7:72-77

Reamer DC, Zoller WH (1980) Selenium biomethylation products from soil and sewage sludge. Science 208:500-502

Rederstorff M, Krol A, Lescure A (2006) Understanding the importance of selenium and selenoproteins in muscle function. Cell Mol Life Sci 63:52-59

Reeves MA, Hoffmann PR (2009) The human selenoproteome: recent insights into functions and regulation. Cell Mol Life Sci 66:24572478

Refait P, Simon L, Génin J-M (2000) Reduction of $\mathrm{SeO}_{4}{ }^{2-}$ anions and anoxic formation of iron(II)-iron(III) hydroxyl selenate green rust. Environ Sci Technol 34:819-825

Ren Y, Wang Q, Shi L, Yue W, Zhang C, Lei F (2011) Effects of maternal and dietary selenium (Se-enriched yeast) on the expression of $\mathrm{p} 34 \mathrm{cdc} 2$ and CyclinB1 of germ cells of their offspring in goats. Anim Reprod Sci 123:187-191
Ren FL, Guo X, Zhang RJ, Wang SJ, Zuo H, Zhang ZT, Geng D, Yu Y, $\mathrm{Su} \mathrm{M}$ (2007) Effects of selenium and iodine deficiency on bone, cartilage growth plate and chondrocyte differentiation in two generations of rats. Osteoarthritis Cartilage 15:1171-1177

Ren JZ, Zhou ZY, Pan B, Chen W (1987) Selenium distribution in four grassland classes of China. In: Comb GF, Spallholz JE, Levander OA, Oldfield JE (eds) Selenium in biology and medicine. AVI Publishing, New York, pp. 769-774

Risenhoover KL, Bailey JA, Wakelyn LA (1988) Assessing the Rocky Mountain bighorn sheep management problem. Wildl Soc Bull 16:346-352

Robbins CT, Parish SM, Robbins BL (1985) Selenium and glutathione peroxidase activity in mountain goats. Can J Zool 63:1544-1547

Robbins CT (1983) Wildlife feeding and nutrition. Academic, New York

Rosen LE, Walsh DP, Wolfe LL, Bedwell CL, Miller MW (2009) Effects of selenium supplementation and sample storage time on blood indices of selenium status in bighorn sheep. J Wildl Dis 45:795-801

Rosenfeld I, Beath OA (1964) Selenium, geobotany, biochemistry, toxicity and nutrition. Academic, New York

Rucker RB, Fascetti AJ, Keen CL (2008) Trace minerals. In: Kaneko JJ, Harvey JW (eds) Clinical biochemistry of domestic animals, 6th edn. Academic, Burlington, pp 663-694

Sarathchandra SU, Watkinson JH (1981) Oxidation of elemental selenium to selenite by Bacillus megaterium. Science 211:600-601

Sakuma Y, Matsuoka K, Honda C, Matsumoto K, Endo K (2008) Dynamics of redox related elements $(\mathrm{Fe}, \mathrm{Co}, \mathrm{Zn}$, and $\mathrm{Se})$ and oxidative stress caused by Se-deficiency in rats. J Radioanal Nucl Chem 278:591-594

Samson J, Jorgeson JT, Wishart WD (1989) Glutathione peroxidase activity and selenium levels in Rocky Mountain bighorn sheep and mountain goats. Can J Zool 67:2493-2496

Sargison ND, West MD, Clark RG (1998) The effect of iodine deficiency on ewe fertility and perinatal lamb mortality. NZ Vet J 46:72-75

Schlumberger HG (1955) Spontaneous goiter and cancer of the thyroid in animals. Ohio J Sci 55:23-43

Schubert JR, Muth OH, Oldfield JE, Remmert LF (1961) Experimental results with selenium in white muscle disease of lambs and calves. Fed Proc 20:689-694

Schwarz K, Foltz CM (1957) Selenium as an integral part of factor 3 against dietary liver degeneration. J Am Chem Soc 79:3292-3293

Serdaru M, Vlădescu L, Țolea I (2004) Fluorimetric study of the selenium course in the dam-calf relationship. Biol Trace Elem Res 99:113-121

Shchedrina VA, Zhang Y, Labunskyy VM, Hatfield DL, Gladyshev VN (2010) Structure-function relations, physiological roles, and evolution of mammalian ER-resident selenoproteins. Antiox Redox Signal 12:839-849

Shrift A (1964) A selenium cycle in nature? Nature 201:1304-1305

Sivertsen T (2004) Connections between regional geochemistry and trace element problems in sheep in Norway. In: Steinnes E (ed) Geomedical aspects of organic farming. Norwegian Academy of Science and Letters, Oslo, pp 65-70

Sleeman JM, Manning EJ, Rohm JH, Sims JP, Sanchez S, Gerhold RW, Keel MK (2009) Johne's disease in a free-ranging white-tailed deer from Virginia and subsequent surveillance for Mycobacterium avium subspecies paratuberculosis. J Wildl Dis 45:201-206

Sleeman JM, Magura K, Howell J, Rohm J, Murphy LA (2010) Hepatic mineral values of white-tailed deer (Odocoileus virginianus) from Virginia. J Wildl Dis 46:525-531

Slemr F, Langer E (1992) Increase in global atmospheric concentrations of mercury inferred from measurements of the Atlantic Ocean. Nature 355:434-437

Sørmo EG, Ciesielski TM, Øverjordet IB, Lierhagen S, Eggen GS, Berg T, Jenssen BM (2011) Selenium moderates mercury toxicity in freeranging freshwater fish. Environ Sci Technol 45:6561-6566 
Sors TG, Ellis DR, Salt DE (2005) Selenium uptake, translocation, assimilation and metabolic fate in plants. Photosyn Res 86:373-389

Stadtman TC (1990) Selenium biochemistry. Annu Rev Biochem $59: 111-127$

Starkley EE, deCalesta DS, Witmer GW (1982) The management of Roosevelt elk habitat and harvest. Trans N Am Wildl Nat Res Conf 47:353-362

Steinhöfel O, Wachs S, Wacker K (2004) Untersuchungen zur Durchführbarkeit und den Auswirkungen von Landnutzungsänderungen auf dem Grünland in den Elbauen. Schrift Sächsischen Landesanst Landwirtsch 9:1-97

Steinnes E, Rambaek JP, Hanssen JE (1992) Large scale multi-element survey of atmospheric deposition using naturally growing moss as a biomonitor. Chemosphere 25:735-752

Stephenson TR, Crouse JA, Hundertmark KJ, Keech MA (2001) Vitamin E, selenium, and reproductive losses in Alaskan Moose. Alces 37:201-206

Stoszek MJ, Willmes H, Jordan NL, Kessler WB (1980) Natural trace mineral deficiency in native pronghorn antelope populations. Proceedings of the 9th Biennial Pronghorn Antelope Workshop, Rio Rico, AZ, USA, pp 71-76

Suttle NF (2010) Selenium. In: Suttle NF (ed) Mineral nutrition of livestock, 4th edn. CABI Publishing, Oxon, pp 377-425

Swaine DJ (1978) Selenium: from magma to man. In: Hemphill DD (ed) Trace substances in environmental health-XII. University of Missouri Press, Missouri, pp 129-134

Tachi Y, Shibutani T, Sato H, Yui M (1998) Sorption and diffusion behavior of selenium in tuff. J Contam Hydro 35:77-88

Tate WP, Mansell JB, Mannering SA, Irvine JH, Major LL, Wilson DN (1999) UGA: a dual signal for 'stop' and for recoding in protein synthesis. Biochemistry 64:1342-1353

Taylor EW, Nadimpalli RG, Ramanathan CS (1997) Genomic structures of viral agents in relation to the biosynthesis of selenoproteins. Biol Trace Elem Res 56:63-91

Thompson ME, Roach C, Braddock W (1956) New occurrences of native selenium. Am Mineral 41:156-157

Tiedemann AR, Klemmedson JO, Bull EL (2000) Solution of forest health problems with prescribed fire: are forest productivity and wildlife at risk? For Ecol Manage 127:1-18

Turanov AA, Xu XM, Carlson BA, Yoo MH, Gladyshev VN, Hatfield DL (2011) Biosynthesis of selenocysteine, the 21st aminoic acid in the genetic code, and a novel pathway for cysteine biosynthesis. Adv Nutr 2:122-128

Ullrey DE, Youatt WG, Whetter PA (1981) Muscle selenium concentrations in Michigan deer. J Wildl Manage 45:534-536

Ulrich JM, Shrift A (1968) Selenium absorption by excised Astragalus roots. Plant Physiol 43:14-20

Usuki F, Yamashita A, Fujimura M (2011) Post-transcriptional defects of antioxidant selenoenzymes cause oxidative stress under methylmercury exposure. J Biol Chem 286:6641-6649

Van Dorst SH, Peterson PJ (1984) Selenium speciation in the soil solution and its relevance to plant uptake. J Sci Food Agric 35:601-605

Van Metre DC, Callan RJ (2001) Selenium and vitamin E. In: Van Metre DC (ed) Update on small ruminant medicine. Veterinary Clinics of North America: Food Animal Practice vol 17(2). W.B. Saunders, Philadelphia

Van Reenen G (1980) Trace elements and deer management. Deer Farmer 4:25-31

Vikøren T, Kristoffersen AB, Lierhagen S, Handeland K (2011) A comparitive study of hepatic trace element levels in wild moose, roe deer, and reindeer from Norway. J Wildl Dis 41:569-579

Vikøren T, Bernhoft A, Waaler T, Handelan K (2005) Liver concentrations of copper, cobalt and selenium in wild Norwegian red deer (Cervus elaphus). J Wildl Dis 41:569-579

Von Kerckerinck zur Borg J (1987) Deer farming in North America. Phanter Press, Rhinebeck
Voudouri AE, Chadio SE, Menegatos JG, Zervas GP, Nicol F, Arthur JR (2003) Selenoenzyme activities in selenium- and iodinedeficient sheep. Biol Trace Elem Res 94:213-224

Wang Z, Gao Y (2001) Biogeochemical cycling of selenium in Chinese environments. Appl Geochem 16:1345-1351

Wang C, Wang H, Luo J, Hu Y, Wei L, Duan M, He H (2009) Selenium deficiency impairs host innate immune response and induces susceptibility to Listeria monocytogenes infection. BMC Immunol 10:55. doi:1186/1471-2172-10-55

Wang HF, Takematsu N, Ambe S (2000) Effects of soil acidity on the uptake of trace elements in soybean and tomato plants. Appl Radiat Isot 52:803-811

Webb JS, Atkinson WJ (1965) Regional geochemical reconnaissance applied to some agricultural Problems in Co. Limerick, Eire. Nature 208:1056-1059

Weiss HV, Koide M, Goldberg ED (1971) Selenium and sulfur in a Greenland ice sheet: relation to fossil fuel combustion. Science 172:261-263

Whanger PD (1992) Selenium in the treatment of heavy-metal poisoning and chemical carcinogenesis. J Trace Elem Electrol Health Dis 6:209-221

White PJ, Bowen HC, Marshal B, Broadley MR (2007) Extraordinarily high leaf selenium to sulfur ratios define Se-accumulator plants. Ann Bot 100:111-118

White PJ, Bowen HC, Parmaguru P, Fritz M, Spracklen WP, Spiby RE, Meachem MC, Mead A, Harriman M, Trueman LJ, Smith BM, Thomas B, Broadley MR (2004) Interactions between selenium and sulfur nutrition in Arabidopsis thaliana. J Expt Bot 55:19271937

Wichtel JJ, Freeman DA, Varela-Alvarez H, Williamson NB, Craigie AL (1996) Effect of selenium and iodine supplementation on growth rate and on thyroid and somatotropic function in dairy calves at pasture. J Dairy Sci 79:1866-1872

Williams MW, Losleben MV, Hamann HB (2002) Alpine areas in the Colorado Front Range as monitors of climate change and ecosystem response. Geogr Rev 92:180-191

Wilson PR, Bell M, Walker IH, Quinn A, Woolderink M (2002) Iodine and calf survival. NZVA Deer Branch Conf Proc 19:105-112

Wilson PR, Grace ND (2001) A review of tissue reference values used to assess the trace element status of farmed red deer (Cervus elaphus). NZ Vet J 49:126-132

Yang J, Hu Y, Bu R (2006) Microscale spatial variability of redox potential in surface soil. Soil Sci 171:747-753

Yoshioka K, Domi M, Wang S, Li Y, Xia Z, Oyamada T, Yoshikawa H, Yoshikawa T (2000) Hepatic ceroid-lipofuscinosis in enzootic cardiomyopathy of Sika deer (Cervus nippon Temminck). J Comp Pathol 123:67-71

Ytrehus B, Skagemo H, Stuve G, Sivertsen T, Handeland K, Vikoren T (1999) Osteoporosis, bone mineralization, and status of selected trace elements in two populations of moose calves in Norway. J Wildl Dis 35:204-211

Zagrodzki P, Nicol F, McCoy MA, Smyth JA, Kennedy DG, Arthur JR (1998) Iodine deficiency in cattle: compensatory changes in thyroidal selenoenzymes. Res Vet Sci 64:209-211

Zayed A, Lytle CM, Terry N (1998) Accumulation and volatilization of different chemical species of selenium by plants. Planta 206:284 292

Zhang Y, Frankenberger WT Jr (2000) Formation of dimethylselenonium compounds in soil. Environ Sci Technol 34:776783

Zieve R, Peterson PJ (1984) Volatilization of selenium from plants and soils. Sci Total Environ 32:197-202

Zimmerman TJ, Jenks JA, Leslie DM Jr, Neiger RD (2008) Hepatic minerals of white-tailed and mule deer in the southern Black Hills, South Dakota. J Wildl Dis 44:341-350 